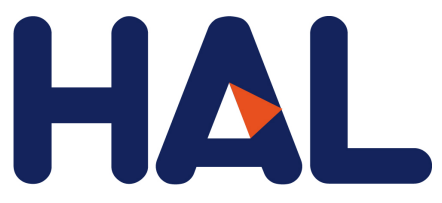

archives-ouvertes

\title{
Aeromagnetic patterns in Southern Uruguay: Precambrian-Mesozoic dyke swarms and Mesozoic rifting structural and tectonic evolution
}

Pablo Demarco, Henri Masquelin, Claudia Prezzi, Tahar Aifa, Rossana Muzio, Judith Loureiro, Elena Peel, Nestor Campal, Leda Sánchez Bettucci

\section{To cite this version:}

Pablo Demarco, Henri Masquelin, Claudia Prezzi, Tahar Aifa, Rossana Muzio, et al.. Aeromagnetic patterns in Southern Uruguay: Precambrian-Mesozoic dyke swarms and Mesozoic rifting structural and tectonic evolution. Tectonophysics, Elsevier, In press, 10.1016/j.tecto.2020.228373 . insu02878330

HAL Id: insu-02878330

https://hal-insu.archives-ouvertes.fr/insu-02878330

Submitted on 23 Jun 2020

HAL is a multi-disciplinary open access archive for the deposit and dissemination of scientific research documents, whether they are published or not. The documents may come from teaching and research institutions in France or abroad, or from public or private research centers.
L'archive ouverte pluridisciplinaire HAL, est destinée au dépôt et à la diffusion de documents scientifiques de niveau recherche, publiés ou non, émanant des établissements d'enseignement et de recherche français ou étrangers, des laboratoires publics ou privés. 


\title{
Aeromagnetic patterns in Southern Uruguay: Precambrian-Mesozoic dyke swarms and Mesozoic rifting structural and tectonic evolution
}

\author{
Pablo Nuñez Demarco ${ }^{\mathrm{a}, \mathrm{b}}, *$, Henri Masquelin ${ }^{\mathrm{a}}$, Claudia Prezzi ${ }^{\mathrm{b}}$, Tahar Aïfa ${ }^{\mathrm{c}}$, Rossana Muzio ${ }^{\mathrm{a}}$, \\ Judith Loureiro $^{\mathrm{d}}$, Elena Peel ${ }^{\mathrm{a}}$, Nestor Campal ${ }^{\mathrm{d}}$, Leda Sánchez Bettucci ${ }^{\mathrm{a}, \mathrm{d}}$ \\ a Instituto de Ciencias Geológicas, Facultad de Ciencias, Universidad de la República, Montevideo, Uruguay \\ ${ }^{\mathrm{b}}$ IGeBa, Facultad de Ciencias Exactas y Naturales, Universidad de Buenos Aires, Buenos Aires, Argentina \\ ${ }^{\mathrm{c}}$ CNRS, Géosciences Rennes - Universite Rennes, Rennes, France \\ ${ }^{\mathrm{d}}$ Dirección Nacional de Minería y Geología, Montevideo, Uruguay
}

\section{A R T I C L E I N F O}

\section{Keywords:}

Aeromagnetic data

Dyke swarm

Shear zones

Mesozoic Rift

Transfer zone

Southern Uruguay

\begin{abstract}
A B S T R A C T
New high-resolution airborne magnetic data of Uruguay allowed constructing new maps concerning the spatial distribution of dyke swarms, main faults and other magnetic bodies, which compose the Uruguayan Shield. We combined geophysical analyses (vertical derivatives, upward continuation, Euler deconvolution), structural analyses of the magnetic maps and previous geological data in order to discriminate the main structural features of the Uruguayan Shield and contribute to a better understanding of its tectonic evolution.

The magnetic maps revealed several outstanding features in the Uruguayan Shield. The Paleoproterozoic dyke swarm is larger, denser, more widespread and complex than originally thought, suggesting a possible plume origin. In addition, a new Mesozoic dyke swarm, as complex as the previous one, was identified crosscutting the Paleoproterozoic dyke swarm and the Neoproterozoic orogenic structures. Moreover, this swarm is connected to volcanic calderas in the Merín basin, and shows displacements along Neoproterozoic shear zones, in the magnetic maps, revealing its brittle reactivation during Mesozoic times.

The new observations clarify how Proterozoic basement structures controlled the development of the Mesozoic rift. Paleoproterozoic dyke swarms were reactivated as normal faults and Neoproterozoic structures hindered the rift growth, deflecting the deformation in transcurrent movements. Meanwhile, the Mesozoic dyke swarm was developed in a perpendicular direction to the Neoproterozoic structures. Moreover, these findings contradict the current rift model for Uruguay and rise a new model in which the Mesozoic rift developed as two rift basins connected by a central transfer zone, generated by the reactivation of Dom Feliciano Belt structures, between the Sierra Ballena and Sarandí del Yí Shear Zones.
\end{abstract}

\section{Introduction}

The Uruguayan Shield (Fig. 1) is a complex collage of Archean to Neoproterozoic blocks, with different histories. It experienced a complex amalgamation since Paleoproterozoic times that ended with a Neoproterozoic orogenic event (Sánchez Bettucci and Rapalini, 2002 and references therein; Rossello et al., 2007; Sánchez Bettucci et al., 2010; Oyhantçabal et al., 2011; Masquelin et al., 2017; Núñez Demarco et al., 2018, 2019b; Bologna et al., 2019). Later, it suffered a Mesozoic extensional event related to the opening of the Atlantic Ocean. The structural records of these events are interrelated and superimposed. Reactivation, inversion, deformation, displacement and obliteration of previous structures are common and not well understood. This makes it difficult to separate events and to understand their complex history (Masquelin et al., 2017; Núñez Demarco et al., 2018, 2019b; Bologna et al., 2019; among others).

Recent aeromagnetic surveys carried out by Dirección Nacional de Minería y Geología (MIEM-DINAMIGE) revealed dense and complex magnetic structures crosscutting the Uruguayan basement, increasing the complexity of the interpretation of structural events of the Uruguayan geology. This geophysical survey shows that the Uruguayan Shield (Fig. 2) is crosscut by different dyke swarms, corresponding to distinct plumbing systems of consecutive large igneous provinces (Coffin and Eldholm, 1994; Bryan and Ernst, 2008; Ernst, 2014), which can be ordered by relative age taking into account stratigraphic relationships. The oldest dyke swarm known in Uruguay is the mafic

\footnotetext{
* Corresponding author at: Instituto de Ciencias Geológicas, Facultad de Ciencias, Universidad de la República, Montevideo, Uruguay.

E-mail address: pnunez@fcien.edu.uy (P. Nuñez Demarco).
} 


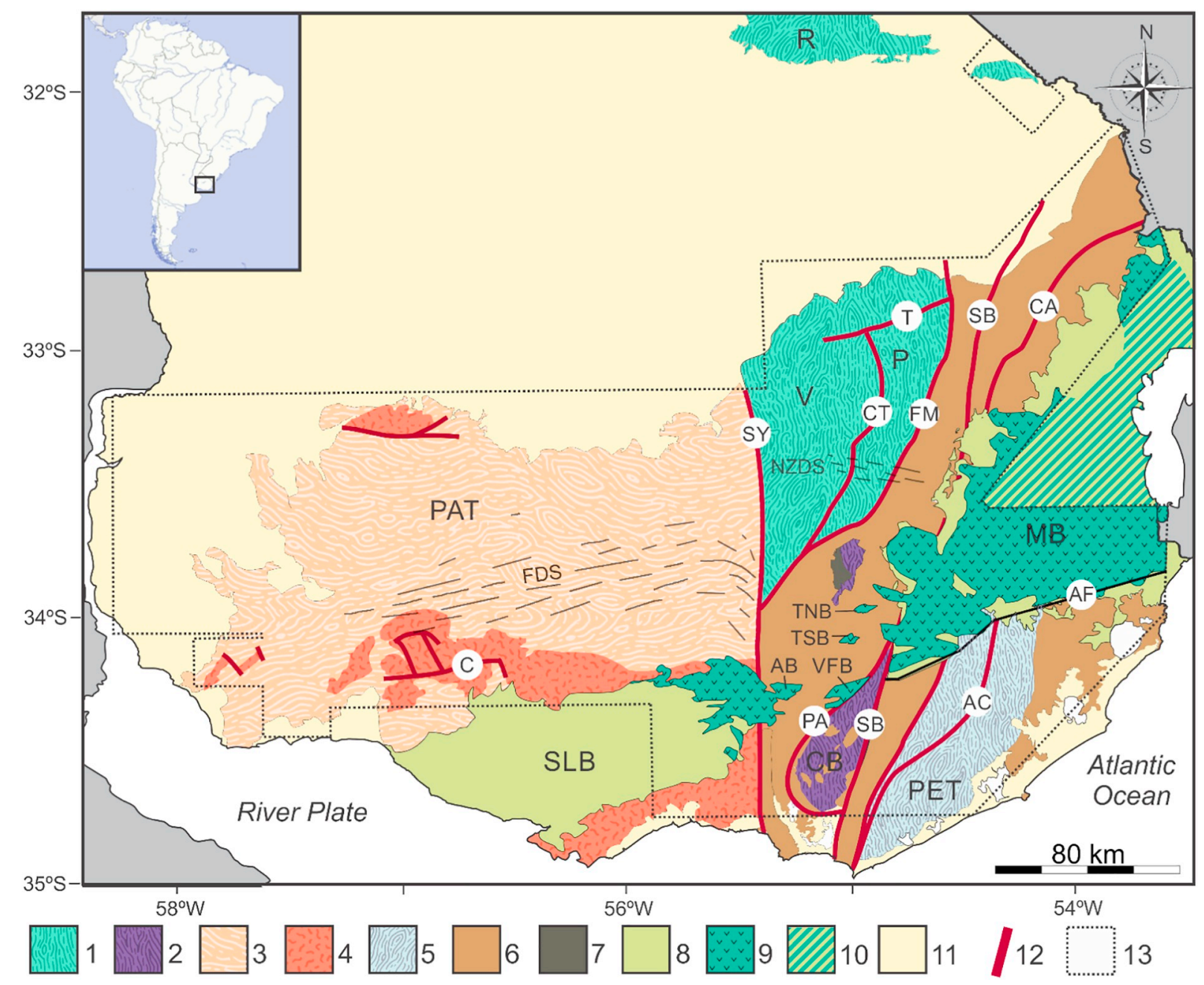

Fig. 1. Uruguayan structural map. (1) Archean to Paleoproterozoic Nico Pérez Terrane (NPT) composed of blocks: Rivera (R), Valentines (V) and Pavas (P); (2) Proterozoic basement of the Dom Feliciano Belt, Campanero Block (CB); (3) Paleoproterozoic Piedra Alta Terrane (PAT); (4) Paleoproterozoic Orogenic Belts (schists and granitoids):; (5) Punta del Este Terrane (PET); (6) Neoproterozoic Dom Feliciano Belt (schists and granitoids), (7) Barriga Negra Formation; (8) Mesozoic sedimentary rocks; (9) Mesozoic bimodal igneous rocks; (10) undifferentiated Mesozoic rocs (8-10) Mesozoic Rift Basins: Santa Lucia (SLB), Merín (MB), Tapes Norte (TNB) and Tapes Sur (TSB), Arequita (AB), Valle Fuentes (VFB); (11) Other Phanerozoic Basins; (12) Main Proterozoic structural limits; (13) Study area, covered by high resolution aeromagnetics (see Fig. 2). Shear Zones: Cufré (C), Sierra Ballena (SB), Sarandí del Yí (SY), Cueva del Tigre-Sierra de Sosa (CT), Fraile Muerto-Maria Albina (FM), Otazo-Cerro Amaro (CA), Alférez-Cordillera (AC), Tupambaé (T) Shear Zones, Pan de Azúcar thrust belt (PA). Major mesozoic structures: Aiguá Fault (AF). General sketches of the previously recognized dyke swarms in Uruguay: Florida Dyke Swarm (FDS), Nico Pérez-Zapicán Dyke Swarm (NZDS) (sensu Lossada et al., 2014, Teixeira et al., 1999).

Florida Dyke Swarm, which is distributed along the Paleoproterozoic Piedra Alta Terrane (Fig. 1) (Bossi and Campal, 1991; Teixeira et al., 1999, 2013), however aeromagnetic data revealed that this dyke swarm is larger, denser, more widespread and complex than originally thought. In addition, a new Mesozoic dyke swarm, as complex as the previous one, here called Nico Pérez-Zapicán Dyke Swarm Group, was identified crosscutting the Paleoproterozoic dyke swarm and the Neoproterozoic orogenic structures This last dyke swarm would be purportedly Cretaceous in age.

The aim of this paper is to analyse the new aeromagnetic data of the Uruguayan crystalline basement applying a combination of structural and geophysical analyses (vertical derivatives, upward continuation, Euler deconvolution) in order to characterize the main magnetic patterns of the Uruguayan Shield. From such characterization, distinct structural features are discriminated and their interrelations, history, crosscut relationships and general kinematics are interpreted. Particularly, new interpretations are proposed regarding the main extensional events that took place in Uruguay during Proterozoic and Mesozoic times. In this regard, dyke swarms are an important tool for the interpretation of petrogenetic and geodynamic processes. They have an extensive areal distribution, can be precisely dated, and may record the ancient geomagnetic field. They are important time-markers, which provide information about extensional processes, allowing accurate paleogeographic reconstructions (Ernst et al., 1996; Hanski et al., 2006). They constitute a fundamental tool for understanding rift kinematics, magmatic activity, large igneous provinces genesis and development, correlation between different tectonomagmatic provinces and plate motions (Ernst and Buchan, 1997; Reeves, 2000). They can also allow to determine the existence and location of fractures, shear zones and mantle plume centers, they can reflect pre-existing structures of the lithosphere (Modisi et al., 2000), paleostress regimes (Anderson, 1951; Creixell et al., 2011) and host economic mineralizations (Modisi et al., 2000; Ernst and Buchan, 2001). Detailed aeromagnetic surveys allow detecting and mapping dyke swarms that are not exposed, becoming a fundamental tool in their study (Mubu, 1995; Modisi et al., 2000). Although the magnetic signature of a dyke is usually easy to recognize, little attention has been paid to the important problem of magnetically identifying dykes with common trend but dissimilar ages within a 


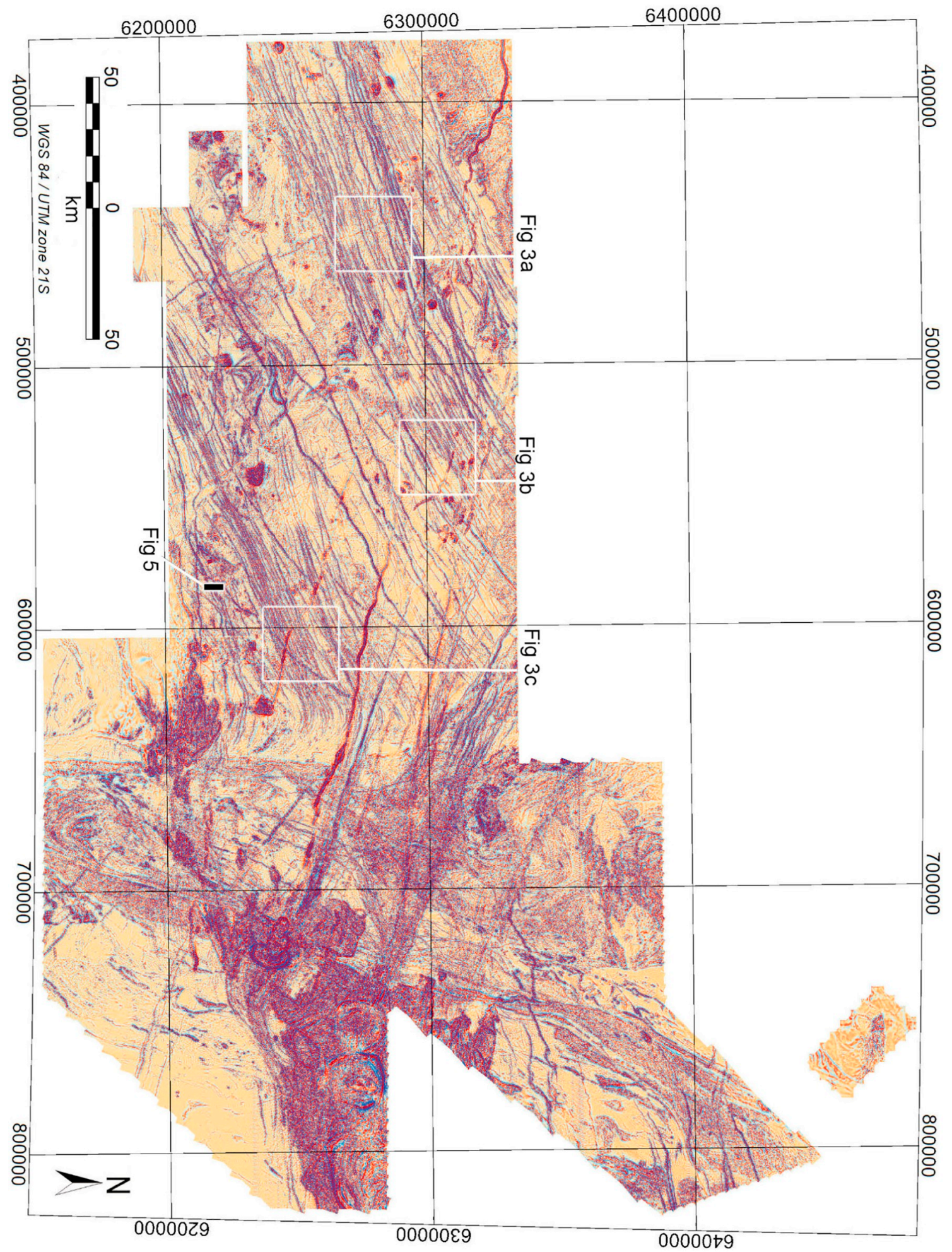

Fig. 2. Second vertical derivative of the aeromagnetic anomaly of the Uruguayan Shield. Location area is shown in Fig. 1 by a dotted black line.

single swarm. There are likely to be significant differences in magnetic signature, although the identification and mapping of these differences would require inputs from both field and laboratory studies. Folding and fractures in dykes can also be an important indicator of strike-slip movements and even compressive kinematics. Moreover, cross-cutting relationships make dykes valuable stratigraphic and kinematic markers (Escher et al., 1975; Hou et al., 2010; Oriolo et al., 2015, among others).

\section{Geologic setting}

The Uruguayan Shield is composed by a collage of Precambrian terranes and schist belts (Masquelin, 2006; Núñez Demarco et al., 2018; and references therein). From west to east the main terranes and belts are: (i) Piedra Alta Terrane (PAT, Bossi et al., 1993a), (ii) Nico Pérez Terrane (NPT, Bossi and Campal, 1992), (iii) Dom Feliciano Belt (Fragoso-Cesar, 1980; Sánchez Bettucci et al., 2010) and, (iv) Punta del 
Este Terrane (PET, Preciozzi et al., 1999; Masquelin, 2006; Basei et al., 2011). These terranes and belts are separated by ductile strike-slip shear zones (Fig. 1).

\subsection{Proterozoic basement}

The Piedra Alta Terrane (PAT) outcrops in the southwestern part of Uruguay and limits to the east with the Nico Pérez Terrane along the NS Sarandí del Yí Shear Zone (SY, Preciozzi et al., 1979: Bossi and Campal, 1992) (Fig. 1). The Piera Alta Terrane includes EW trending low-grade metamorphic belts, granitoids of ca. $2.1 \mathrm{Ga}$ and the mafic Florida Dyke Swarm (FDS) of ca. 1.79 Ga (Bossi and Campal, 1991; Teixeira et al., 1999; Hartmann et al., 2000; Halls et al., 2001; Bossi and Cingolani, 2009; Oyhantçabal et al., 2011).

The Nico Pérez Terrane (NPT) is composed by several ArcheanPaleoproterozoic blocks, e.g. Valentines (V), Rivera (R) and Pavas (P) blocks (Fig. 1) representing different geological units. Their geological history includes the occurrence of Paleoproterozoic magmatism and metamorphism, as well as Neoproterozoic granitic intrusions. The NESW trending Fraile Muerto-Maria Albina Shear Zone (FM), along its southeastern border, is considered the limit with the Dom Feliciano Belt (Sánchez Bettucci et al., 2010).

The Dom Feliciano Belt (Fig. 1) is composed by geological units originated, deformed and/or metamorphosed during the Brasiliano/ Pan-African orogenic cycle (750-550 Ma; Fragoso-Cesar, 1980; Fernandes et al., 1992, Núñez Demarco et al., 2019b, among others), which took place in Uruguay, southern Brazil, and southwestern Africa. It is related to tectonic events that occurred during the Neoproterozoic convergence of the Río de la Plata, Congo and Kalahari Cratons and also to the development of the Kaoko, Gariep and Damara belts in Africa (Porada, 1979, 1989; Prave, 1996; Durr and Dingeldey, 1996; Basei et al., 2005, 2008).

The Punta del Este Terrane (PET, Preciozzi et al., 1999) is located in southeastern Uruguay (Fig. 1), and it is represented by a high-grade metamorphic complex, surrounded by granitoids and metasedimentary successions of the Rocha Formation (Sánchez Bettucci and Mezzano, 1993), also part of the Dom Feliciano Belt. The Alferez-Cordillera (AC) shear zone system is considered as its western limit with the Dom Feliciano Belt (Masquelin, 1990). However, some authors extend it to the Sierra Ballena (SB) Shear Zone (Sánchez Bettucci et al., 2010) (Fig. 1). This terrane is composed by migmatitic paragneisses and orthogneisses metamorphosed under granulite to amphibolite facies conditions. Tonalitic gneisses yielded metamorphic peak ages of ca. 670 Ma (Lenz et al., 2011; Masquelin et al., 2012). They were partially retrograded into greenschist facies rocks during the last brittle-ductile deformation event of the Brasiliano Orogenic Cycle (540-600 Ma).

\subsection{Ductile shear zones}

The Sarandí del Yí (SY) Shear Zone extends along $250 \mathrm{~km}$ with a N-S trend, reaching a width of up to $15 \mathrm{~km}$ (Fig. 1) (Preciozzi et al., 1979; Oyhantçabal, 2005; Oriolo et al., 2016a, 2016b). Bossi and Campal (1992) suggested that this shear zone is dextral, based on the curvature of the mafic Florida Dyke Swarm (FDS), which is a kinematic indicator. Oyhantçabal (2005) proposed a superimposed sinistral movement, suggesting a Paleoproterozoic age for the first dextral phase and a Neoproterozoic one for the sinistral reactivation. Oriolo et al. (2016a, 2016b) documented that magmatic U-Pb zircon ages linked to the occurrence of mylonites along this shear zone constrained dextral movement to the Neoproterozoic (ca. $600 \mathrm{Ma}$ ). Meanwhile, the sinistral movement was constrained by S-C structures and porphyroblasts of a syn-kinematic granite at ca. 594-584 Ma (Oyhantçabal et al., 2001, 2009). Magnetotelluric studies (Bologna et al., 2019) show that this sinistral shear zone has no significative expression in the lithosphere and does not represent a Neoproterozoic continental suture, as previously suggested (Bossi and Cingolani, 2009; Gaucher et al., 2011; among others).

The Sierra Ballena (SB) Shear Zone is considered a sinistral suture extending from Punta Ballena Peninsula in Uruguay into Brazil (Fig. 1), where it continues as the Dorsal de Canguçu Shear Zone or Pedras Altas Shear Zone (sensu Fernandes et al., 1992, 1995; Gómez Rifas, 1995; Basei and Teixeira, 1987; Basei et al., 2000, 2005; among others). It is also considered as an intraplate shear zone related to oblique collision (Fragoso-Cesar et al., 1987) and as an intraplate shear zone (Oyhantçabal, 2005).

\subsection{Proterozoic mafic dyke swarms}

The Piedra Alta Terrane (PAT) is crosscut by extensional magmatism represented by $N 70^{\circ} \mathrm{E}$ trending subparallel and subvertical, 20 to $80 \mathrm{~m}$ thick dioritic dykes (Preciozzi et al., 1985; Bossi et al., 1993b; Halls et al., 2001). This dyke swarm has received different names over time, it was named as "black granites" (Bossi and Campal, 1991), Ismael Cortinas Mafic Dyke Swarm (Fragoso-Cesar, 1991), Uruguayan Dyke Swarm (Halls et al., 2001), Río de la Plata Dyke Swarm (Maldonado et al., 2003) and Florida Dyke Swarm (FDS, Hartmann et al., 2000; Bossi and Cingolani, 2009; Sánchez Bettucci et al., 2010; Oyhantçabal et al., 2011) (Fig. 1). It is strongly affected by weathering and their identification in the field is difficult. These dykes frequently coincide with depressed topography, and some of them, due to their great thickness, are usually confused with dry river channels or mylonitic zones (Núñez Demarco et al., 2013). Rb-Sr and Ar-Ar dating methods yielded ages ranging between 1.7 and $1.8 \mathrm{Ga}$ (Teixeira et al., 1999). U-Pb (baddeleyite) dating yielded a crystallization age of $1790 \pm 5 \mathrm{Ma}$ (Halls et al., 2001). Also, they can be differentiated according to their $\mathrm{TiO}_{2}$ content. They could be classified as andesites and andesitic basalts of tholeiitic affinity based on the geochemical analysis reported by Teixeira et al. (2013).

\subsection{Mesozoic tectonics}

During the Mesozoic Era the southeastern portion of South America was affected by the break-up of Western Gondwana and the opening of the South Atlantic Ocean (late Jurassic - early Cretaceous) (Vaughan and Pankhurst, 2008; Salomon et al., 2015a, 2015b; Will and Frimmel, 2018; among others). This break-up evolved from south to north and produced multiple aborted rifts along the African and South American margins (Burke and Dewey, 1973). In Uruguay this kind of aulacogenic basins are represented by the Santa Lucia (SLB) and Merín (MB) rift basins (Fig. 1), which were controlled by preexistent structures inherited from the crystalline basement (Mohriak et al., 2002; Muzio, 2006; Rossello et al., 2007).

In southern Uruguay the Mesozoic volcanism filled the Santa Lucia rift basin, which was first described by Jones $(1956,1957)$ through the analysis of the first gravity anomaly data measured in the country and the samples obtained from deep wells. Bossi (1966) extended the graben eastwards to the Merín lagoon. The so-called Santa Lucía and Merín rift basins were firstly considered as germano-type kind grabens (Gómez Rifas, 1989). After that, they were redefined considering a N70 ${ }^{\circ}$ E rifting lineament, known as Santa Lucía-Aiguá-Merín (SaLAM, Rossello et al., 1999, 2000, 2007). According to these authors, this NE trending lineament had a distensive behaviour since the Jurassic and evolved to a strike-slip fault during mid-Cretaceous. The bimodal magmatism within the rift is represented by the basalts of the Puerto Gómez Formation (Serra, 1944; Bossi, 1966; Preciozzi et al., 1985; Muzio, 2000, 2006; Veroslavsky et al., 2006; Spoturno et al., 2012; among others) and the rhyolites/rhyodacites of the Arequita Formation (Bossi, 1966; Bossi and Navarro, 1991; Muzio, 2006; Muzio et al., 2009a, 2009b and references therein).

Santa Lucia rift basin (SLB), mainly located in the Piedra Alta Terrane is approximately 40 to $60 \mathrm{~km}$ wide, and extends symmetrically along a horst with $\mathrm{N}^{\circ} 0^{\circ} \mathrm{E}$ orientation (Fig. 1), whereas its maximum 
depth was estimated in $2.4 \mathrm{~km}$ (Veroslavsky et al., 2006). On other hand, Merín rift basin (MB) (Fig. 1) width can be estimated in ca. $100 \mathrm{~km}$, with a maximum depth of ca. $5 \mathrm{~km}$, whereas it has a relief of $\sim 100 \mathrm{~m}$ in its fault borders (De Santa Ana et al., 1994; Veroslavsky et al., 2006; Cernuschi et al., 2015).

Merín rift basin (MB) was affected, at least, by four volcanic calderalike centers (Valle Chico, Lascano East, Lascano West and San Luis complexes, Fig. 7), characterized by bimodal basalt-rhyolite volcanic rocks with sub-alkaline and alkaline compositions, associated to a distensive brittle episode (Ferrando and Fernández, 1971; Preciozzi et al., 1985; Rossello et al., 1999, 2000; Gómez Rifas and Masquelin, 1996; Muzio, 2000; Morales et al., 2006; Muzio et al., 2002, 2009a, 2009b; Cernuschi et al., 2015). These four caldera-like complexes are related to four huge gravity and magnetic highs of up to $80 \mathrm{mGal}$ and $\sim 1200 \mathrm{nT}$, respectively (SGM, 1973; Reitmayr, 2001; Cernuschi et al., 2015). Such anomalies have been interpreted as indicative of the existence of roofpendant calderas over plutonic magma chambers (Conti, 2008; Cernuschi et al., 2015). The southwestern anomaly is $\sim 20 \mathrm{~km}$ wide and coincident with the syenite outcrops of the Valle Chico intrusive complex (Ferrando and Fernández, 1971; Muzio, 2000). The two central anomalies named Lascano East and Lascano West, are both about $20 \mathrm{~km}$ in diameter and coincide with two sub-circular structures composed by rhyolite-ignimbrite sequences. The easternmost anomaly, named San Luis, corresponds to the largest plutonic-volcanic center, with a diameter of $>30 \mathrm{~km}$, and with granodiorites, granophyres and gabbros exposures only along its southern edge (Cernuschi et al., 2015). Discordant trachytic to rhyolitic dykes crosscut these units with $\mathrm{N} 60^{\circ} \mathrm{E}$ to $\mathrm{E}-\mathrm{W}$ and $\mathrm{N} 20^{\circ} \mathrm{E}$ to $\mathrm{N} 40^{\circ} \mathrm{E}$ trends, respectively (Muzio, 2000; Cernuschi et al., 2015).

Simultaneously, one of the largest flood basalt provinces in the world was developed at the northwestern of Uruguay- northeastern Argentina, east Paraguay and southern Brazil, known as ParanáEtendeka Magmatic Province (ca. $135 \mathrm{Ma}$ ) preceding the opening of the South Atlantic Ocean (Bellieni et al., 1986; Stewart et al., 1996; Peate, 1997; Renne et al., 1992; Muzio, 2006; Thiede and Vasconcelos, 2010; Salomon et al., 2017; among others).

\section{Data acquisition and processing}

The dataset analysed in this work corresponds to high-resolution aeromagnetic data acquired between 2014 and 2015 under the main frame of the Uruguayan Geological Survey (DINAMIGE) (Sánchez Bettucci et al., 2016). The surveyed area is shown in Fig. 1 with a dotted black line, and the second vertical derivative of the aeromagnetic anomaly is shown in Fig. 2. The mean flight elevation was $100 \mathrm{~m}$, along $\mathrm{N}-\mathrm{S}$ trending lines separated by $400 \mathrm{~m}$, with E-W tie lines each $4 \mathrm{~km}$. The International Geomagnetic Reference Field was subtracted from the observed data.

Pole reduction is applied to the data to convert the asymmetric shape of the dipolar anomalies to symmetric ones and to locate anomalies above their source bodies (Baranov, 1957; Baranov and Naudy, 1964; Silva, 1996; Reynolds, 2011; Hinze et al., 2012; Dentith and Mudge, 2014). However, reduction to the pole (RTP) is based on the assumption that induced magnetization of the sources is parallel to the direction of the ambient field. When bodies present dominant remanent magnetization (Koenisberger factor larger than 1), RTP yields anomalous and non-symmetrical patterns (Roest and Pilkington, 1993; Ansari and Alamdar, 2009; Reynolds, 2011; Hinze et al., 2012; Dentith and Mudge, 2014). These anomalous patterns are observed in our data and characterize several studied units. Nevertheless, a careful observation of the pole reduced data leads to discriminate bodies with different anomalous magnetizations, i.e. with normal and anomalous reverse and dipolar signatures (Fig. 3). This expands the mapping capabilities of magnetic objects, despite that its remanent magnetization is not well known. In consequence, RTP data is affected by artefacts and was not used for purposes other than mapping.
Considering all the above mentioned regarding pole reduction, the second vertical derivative of the not reduced to the pole aeromagnetic anomaly was computed (Fig. 2). Despite that the location of body borders is less accurately determined using not reduced to the pole anomalies, the scale of the studied regions and structures make this inaccuracy irrelevant for the purpose of this work. The double differentiation of the aeromagnetic map emphasizes the smaller, weaker and shallower geologic anomalies, that otherwise can be obscured by the presence of magnetic fields associated to deeper features. The second derivative map is also a type of residual map of the observed field, and can be used to delineate contacts of geologic magnetic formations with accuracy (Henderson and Zietz, 1949; Elkins, 1951; Gupta and Ramani, 1982; Reynolds, 2011; Hinze et al., 2012; Dentith and Mudge, 2014).

Euler deconvolution was applied to magnetic anomalies in order to provide preliminary information about the depth and geometrical distribution of the buried magnetic sources. This method is based on Euler's homogeneity equation that associates the potential field and its gradient components to the source location (Hood, 1965; Thompson, 1982; Reid et al., 1990; Reid, 2003; Salem and Smith, 2005). The main advantage of using this method is that it gives realistic solutions and is the less sensitive method to random noise (Bournas et al., 2003). It is independent of the field direction, dip or strike of the magnetic sources (Reid et al., 1990; Roest et al., 1992) and is not affected by magnetic remanence of the rocks (Reid et al., 1990; Ravat, 1996). For the study area, we calculated Euler source points (Fig. 4) using the Oasis Montaj software (Geosoft Inc., 2016). We used a structural index (SI) of 1 and a window size of $1 \mathrm{~km}$, while we set a maximum tolerance of $15 \%$ for depth uncertainty. The SI value was chosen, among the possible ones, considering that it corresponds to the $3 \mathrm{D}$ geometric shape that can better represent the studied dyke swarms and fault systems. The window size was selected in order to individualize only thin sheet structures, like dykes and faults, in the Uruguayan Shield, and corresponds to about half the anomalies width of thin sheet structures. Euler deconvolution was calculated for the not RTP magnetic anomalies because pole reduction produces anomalous signatures, like reverse magnetization of some bodies. In fact, although several authors prefer to work with pole reduced data to obtain more accurate depth estimates, it has been shown that source positions are also accurately reproduced using not RTP magnetic anomalies (Reid et al., 1990). Considering that Euler deconvolution usually produces a large quantity of invalid solutions (due to noise, interference between adjacent anomalies, among others) a small window size was chosen with the aim of isolating anomalies caused by distinct sources. Furthermore, density of solutions was evaluated in order to constrain clusters of solutions (Hsu, 2002; Yao et al., 2004; Chen et al., 2014). Euler solutions were classified in different depth intervals (Fig. 4) trying to identify differences between shallow and deep solutions.

Additionally, structural information was extracted from the magnetic data. Euler deconvolution was calculated for different altitude upward continued magnetic anomalies. This analysis was done under the assumption that upward continuation provides a mean to image sources at deeper crustal depths, allowing obtaining information about the dip of magnetic structures (Archibald et al., 1999; Khattach et al., 2004, 2006; Fedi and Pilkington, 2012). However, interpretations in regions affected by interference between sources were conducted with caution due to possible ambiguities (Fedi and Pilkington, 2012; Pinet et al., 2008; Amar et al., 2015). A random section was selected from the 3D Euler solution map in order to show the distribution of Euler solutions and the resulting structural dip interpretation (Fig. 5). On the other hand, structural directions were measured on the second vertical derivative map, for the different magnetic features, and summarised in rose diagrams in Figs. 6, 7 and 8.

Finally, aeromagnetic data processed using the above techniques was checked and completed with known geological data, in order to generate new structural maps and profiles of the analysed region (Fig. 9). 
a

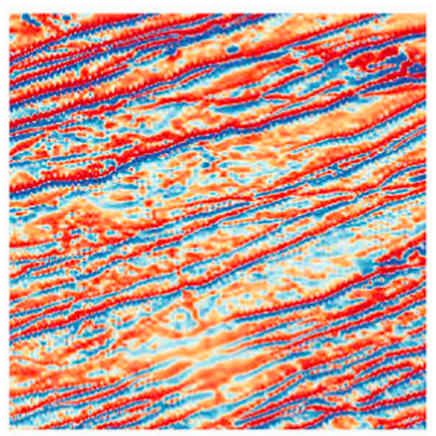

d

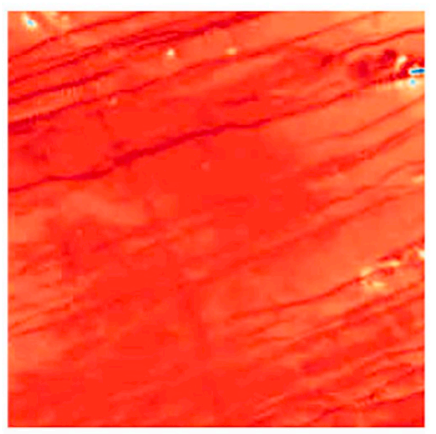

g

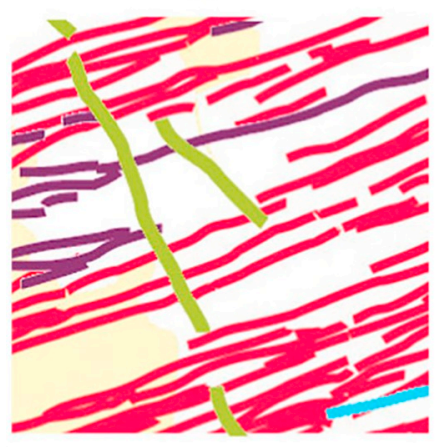

b

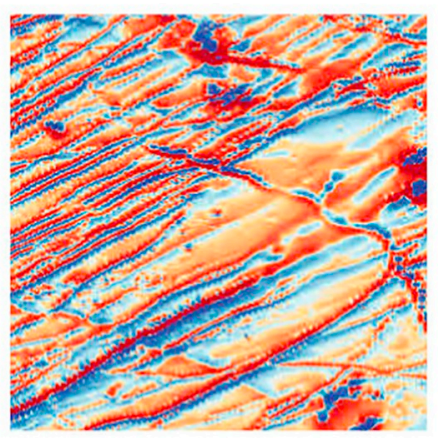

e

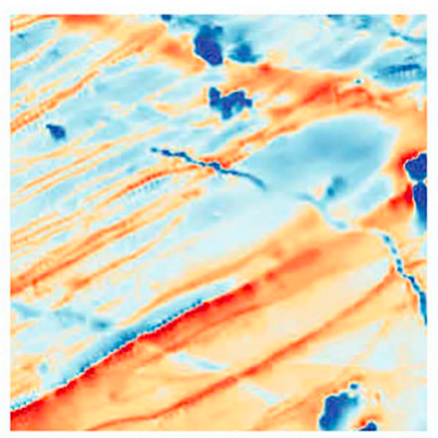

h

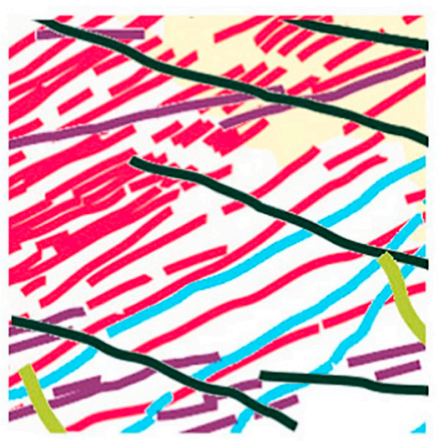

C
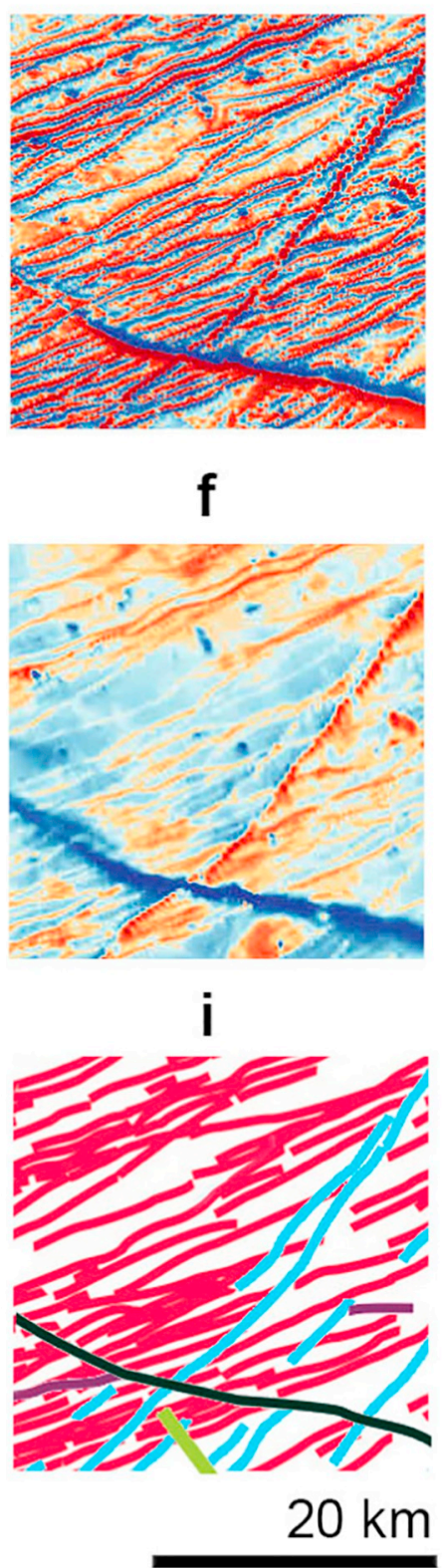

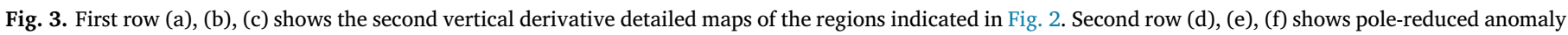

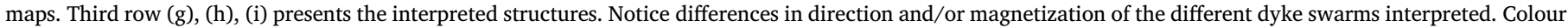
schemes as in Figs. 6 and 8.

\section{Results}

Two main dyke swarms can be identified in Uruguay using aeromagnetic data: the SW-NE-trending Proterozoic mafic Florida Dyke Swarm (FDS) (Fig. 6), and the NW-SE-trending Nico Pérez-Zapicán Mesozoic Dyke Swarm (Fig. 7). These younger dykes, which would correspond to those presumably studied by Mazzucchelli et al. (1995), Lossada et al. (2014) and Cervantes-Solano et al. (2017), crosscut the SSW-NNE-trending lineaments of the Neoproterozoic Dom Feliciano Belt, the EW trending Proterozoic folds and faults of the Piedra Alta Terrane (PAT), and the Florida Dyke Swarm (FDS) (Fig. 1).

Four main magnetic morphostructural units can be identified in the aeromagnetic data analysed in this work: (a) the Florida Dyke Swarm (Fig. 6); (b) the Nico Pérez-Zapicán Dyke Swarm Group (Fig. 7); (c) the Mesozoic Rift Basins, and (d) the Dom Feliciano Belt (Fig. 8).

\subsection{Florida dyke swarm}

Florida Dyke Swarm (FDS) was firstly reported in the literature by Preciozzi et al. (1985). However, dykes dimensions, abundance and mapping were only partially known, mainly due to the meteorization conditions of the Piedra Alta Terrane (PAT) and the scarcity of outcrops, which made geological observations difficult (see Bossi and Campal, 1991; Bossi et al., 1993b; Mazzucchelli et al., 1995; Teixeira et al., 1999; Halls et al., 2001; Bossi et al., 2001; Morales et al., 2010). Aeromagnetic data show that the main mafic Florida Dyke Swarm is a well-defined $>250 \mathrm{~km}$ long and $200 \mathrm{~km}$ wide swarm, with a $\mathrm{N} 70^{\circ} \mathrm{E}$ trend (Fig. 6a). Density and continuity of dykes are greater than previously documented. Individual dykes are at least 200 to $250 \mathrm{~km}$ long, but they continue beyond the studied area reaching unknown lengths. In some sectors there are 1 to 2 dykes per kilometer.

This dyke swarm limits to the east with the Sarandí del Yí (SY) Shear 
a

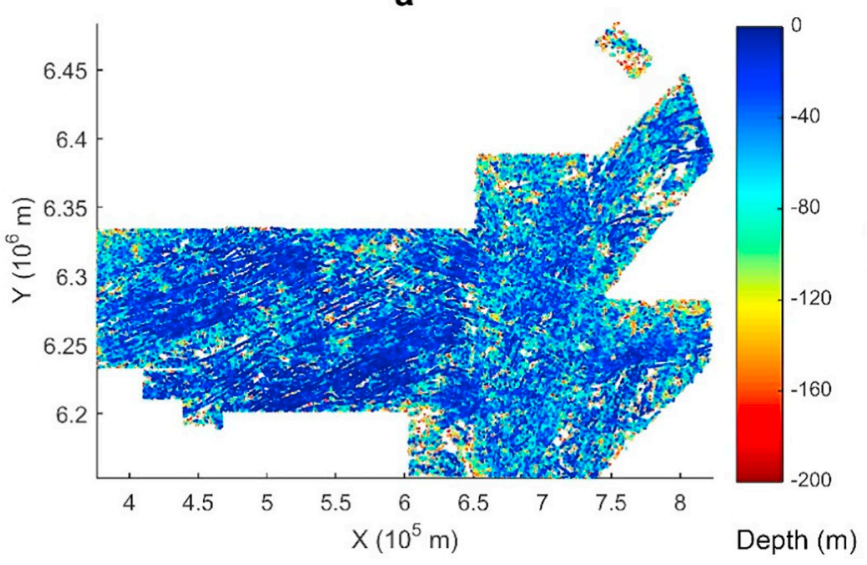

b

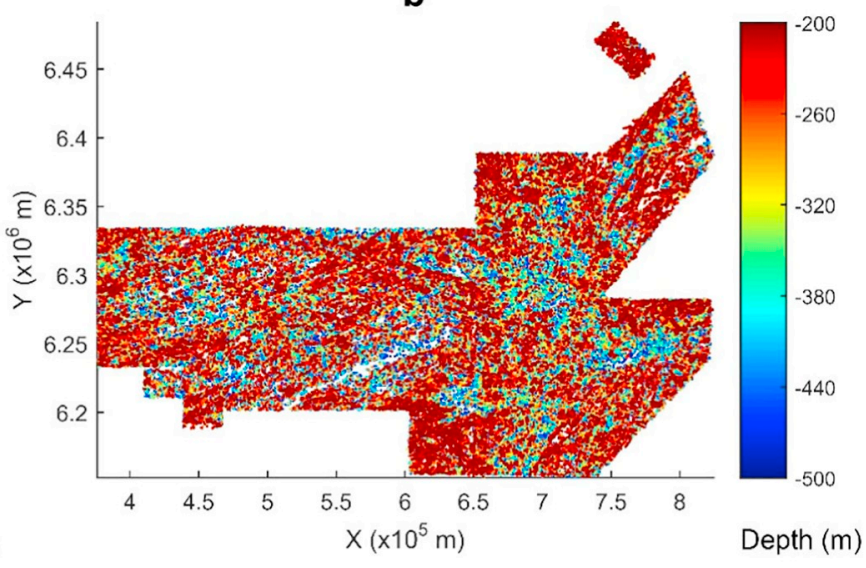

C

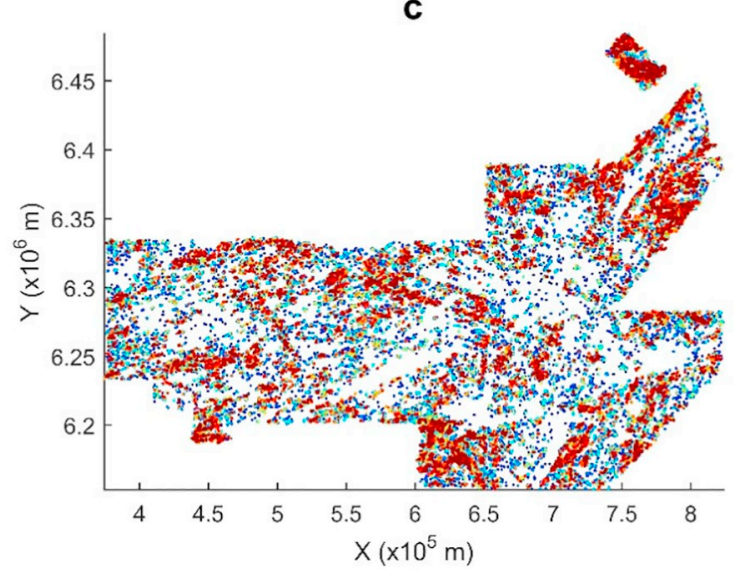

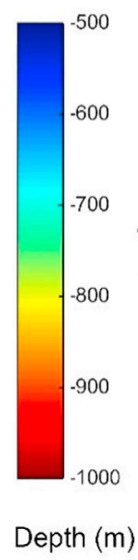

d

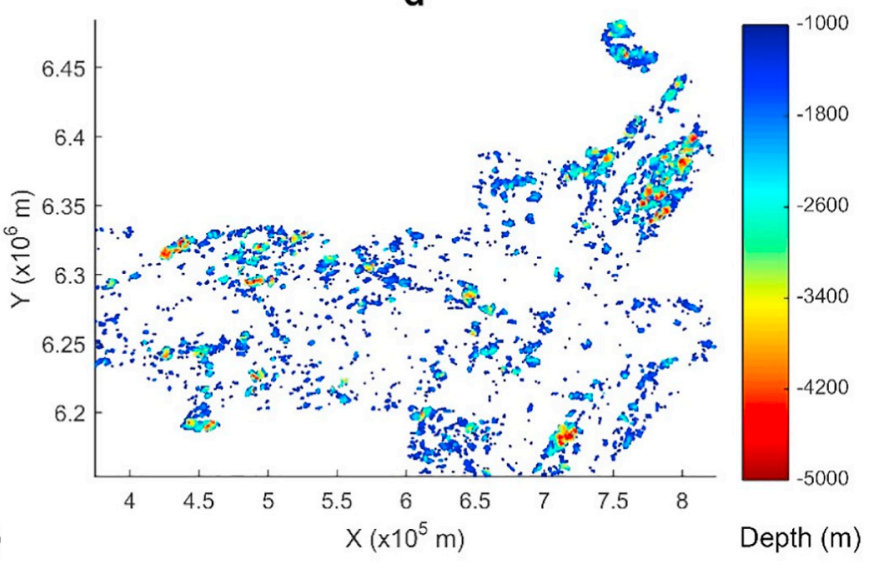

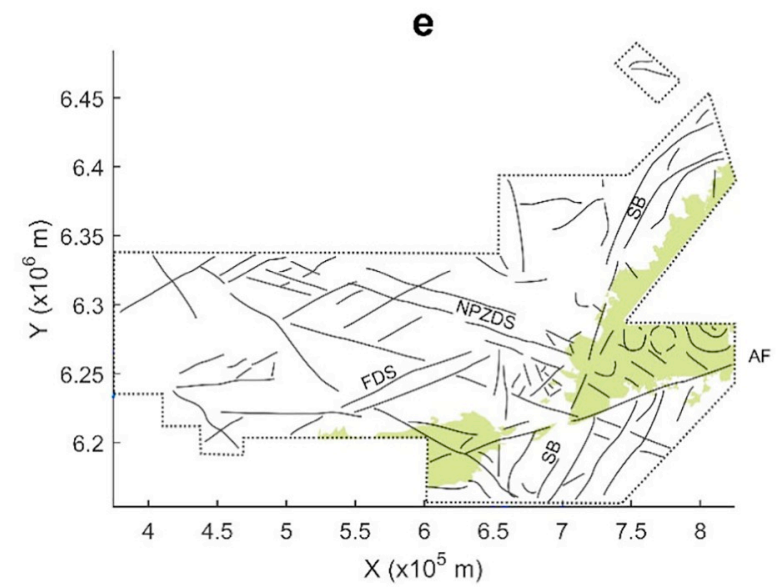

Fig. 4. Euler solutions depths for the not RTP aeromagnetic anomaly for the following depths ranges (a) 0-200 m, (b) 200-500 m, (c) 500-1000 m and (d) 1000-5000 m. (e) Main deep magnetic discontinuities interpreted as structural limits. Mesozoic basins are shown in light green. Main structures related to the main magnetic discontinuities: SB: Sierra Ballena Shear Zone, AF, Aiguá Fault, NPZDS: Nico Pérez-Zapican Dyke Swarm, FDS: Florida Dyke Swarm. (For interpretation of the references to colour in this figure legend, the reader is referred to the web version of this article.)

Zone, along which it was passively folded to the south indicating the occurrence of dextral movement. The minimum horizontal displacement observed in the magnetic maps is of approximately $14-18 \mathrm{~km}$.

Two other associated dyke swarms were also identified by their strikes and magnetic signatures, showing N78 ${ }^{\circ} \mathrm{E}$ and N54 ${ }^{\circ} \mathrm{E}$ trends (Figs. 3, 6b). Density and length of dykes are comparable with the Florida Dyke Swarm. However, intensity of magnetization, magnetization direction (RTP anomalous pattern) and structural trend differ. According to the observed strikes and magnetic signatures, it is highly probable that they are associated to, at least, two different extensional events. Although, it is not possible to determine if they correspond to different magmatic pulses without proper field surveys.

Magnetic maps also reveal that Florida Dyke Swarm and the other two associated dyke families present a gentle flexure of $\sim 10^{\circ}$ to the north in the northern and northeastern limits of the surveyed area, and close to the Sarandí del Yí (SY) Shear Zone (Figs. 2, 6a,b). To the southwest the dykes would extend (covered by phanerozoic deposits) into Argentine territory, where high resolution magnetic data is not available. 

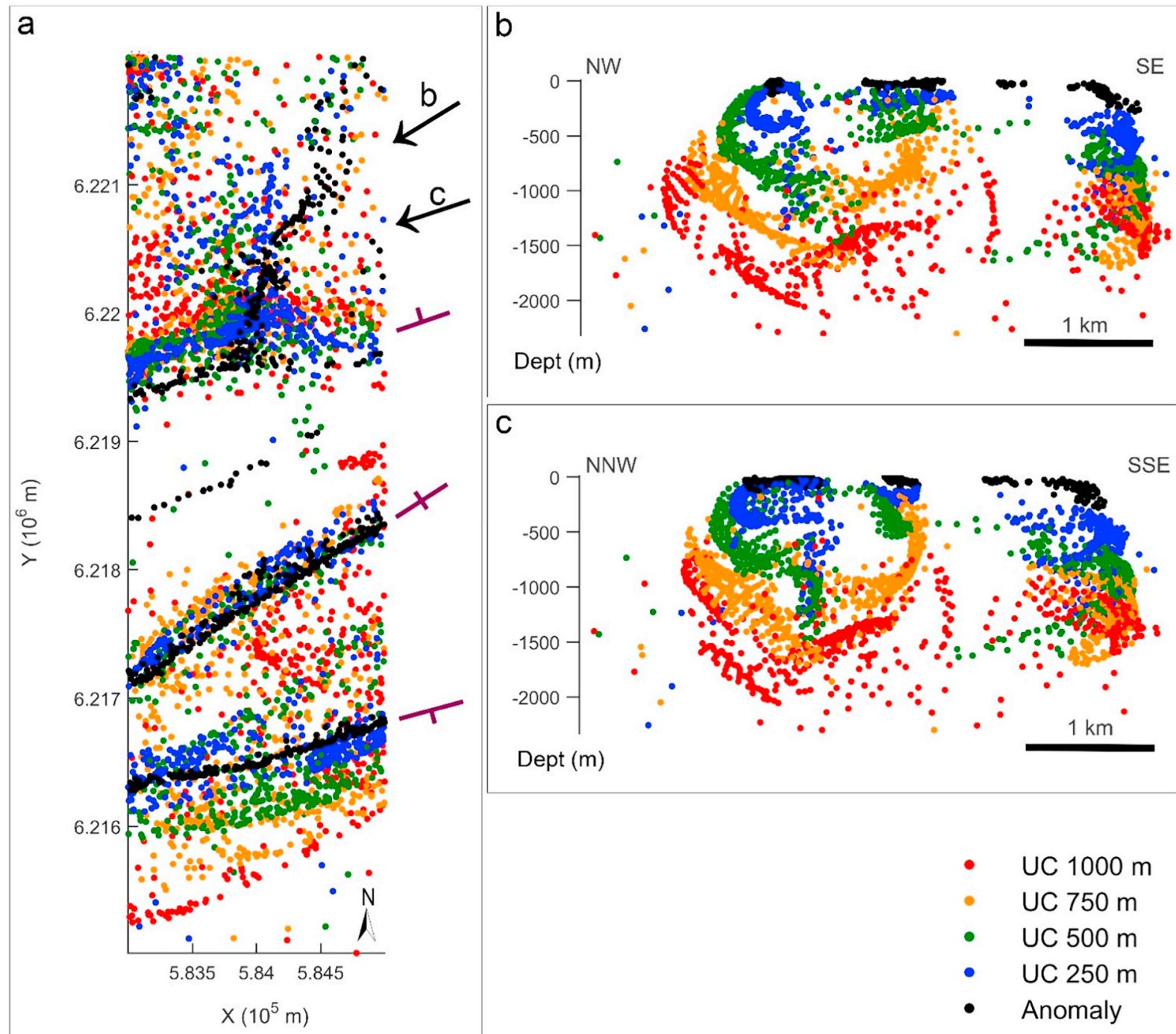

$\operatorname{Dept}(\mathrm{m})$

C

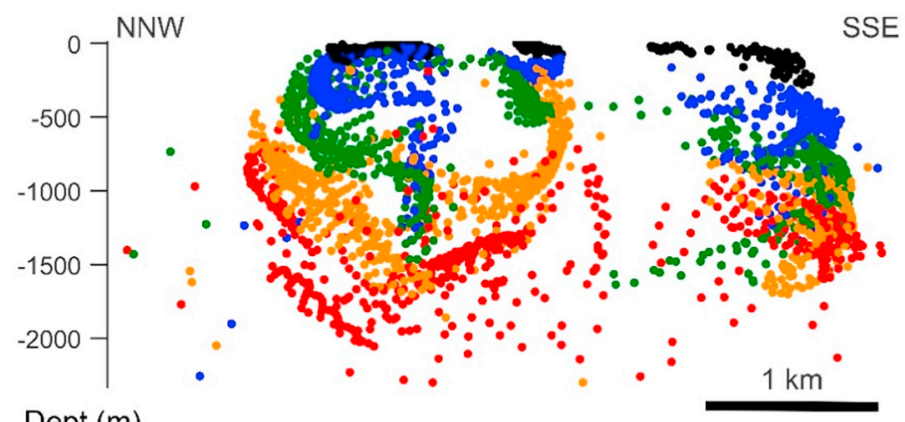

Dept $(m)$

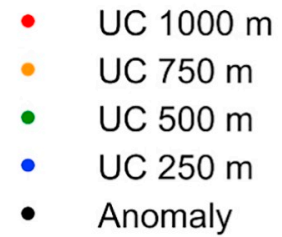

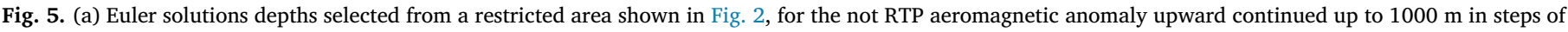

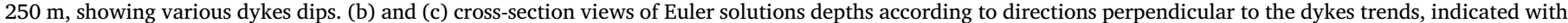
arrows in (a).

\subsection{Nico Pérez-Zapican dyke swarm}

The new aeromagnetic survey reveals the real dimensions of a Mesozoic dyke swarm family trending $\mathrm{N} 100-110^{\circ} \mathrm{E}$ and crosscutting the Uruguayan crystalline basement. Dykes with this trend in the area were previously described by Lossada et al. (2014), in a limited region, as Nico Pérez-Zapican Dyke Swarm (Fig. 7a).

The magnetic survey reveals that this Swarm is composed by scattered individual dykes and $20 \mathrm{~km}$ wide tight dyke sets (subswarms). Each dyke set has a parallel to slightly radial disposition and originate at the center of the Mesozoic volcanic complexes described in the Merín rift basin by Cernuschi et al. (2015); Valle Chico (VC), Lascano East (LE), Lascano West (LW), and San Luis (SL) volcanic centers (Fig. 7). For descriptive purposes, we will refer in this work to each subswarm with the name of their associated caldera: as Valle Chico, Lascano East, Lascano West, and San Luis Dyke Swarms. The Nico Pérez-Zapican Dyke Swarm extends along approximately $350 \mathrm{~km}$, and is $\sim 150 \mathrm{~km}$ wide, showing strikes ranging between $\mathrm{N} 101^{\circ} \mathrm{E}$ to $\mathrm{N} 110^{\circ} \mathrm{E}$. This attitude is almost perpendicular to the Sierra Ballena (SB) Shear Zone (Fig. 7) and to the South Atlantic Margin.

Additionally, Nico Pérez-Zapican Dyke Swarm strike coincides with trends previously observed in northern Uruguay (Gómez Rifas, 1995;
Masquelin et al., 2009; among others) and is parallel to the main dyke swarms of Southern Brazil: Ponta Grossa Dyke Swarm and Eastern Paraguay Dyke Swarm (Renne et al., 1996; de et al., 2007; Salomon et al., 2017) (Fig. 10). Furthermore, the Early Cretaceous Henties BayOutjo Dyke Swarm in Namibia is located at the opposite side of the Atlantic ocean (Trumbull et al., 2004) (Fig. 10).

Two other dyke swarms associated with Mesozoic faulting were also identified. The first one is composed by disperse dykes trending ${\mathrm{N} 89^{\circ} \mathrm{E}}^{\circ}$ that concentrate around the Merín and Santa Lucia rift basins (Fig. 7b). The second one, with a mean trend of $\mathrm{N} 144^{\circ} \mathrm{E}$, is composed by disperse dykes that extend along $300 \mathrm{~km}$. This last swarms crosscut the ArcheanNeoproterozoic basement.

\subsection{Mesozoic rift basins}

The Mesozoic rifting in southern Uruguay generated two main grabens: the Santa Lucía and Merín rift basins, which are perfectly identified in the magnetic maps (Figs. 1 and 2).

Aeromagnetic maps show that the Mesozoic volcanism is concentrated along its eastern boundary (Figs. 1,2) while the magnetic signal of Florida Dyke Swarm is absent or obliterated. However, basin borders are likely controlled by faults trending $\mathrm{N} 070^{\circ} \mathrm{E}$, parallel to the 

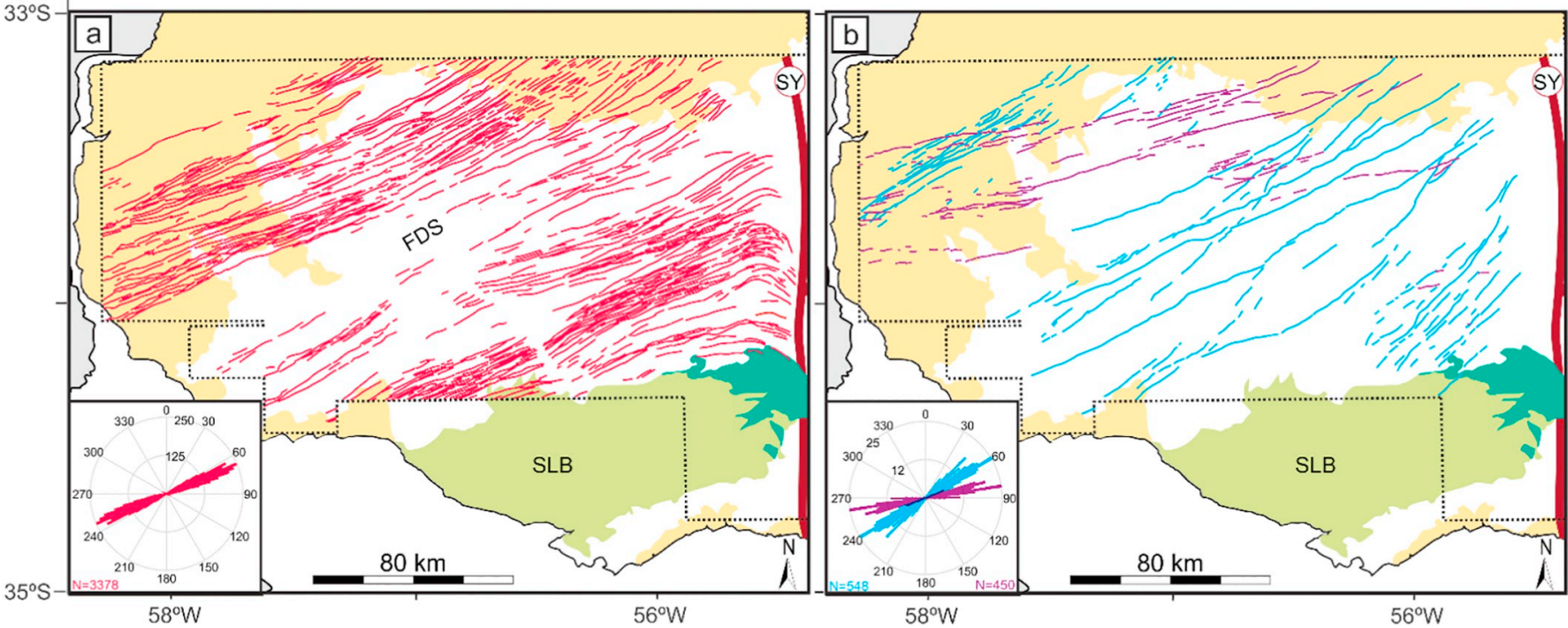

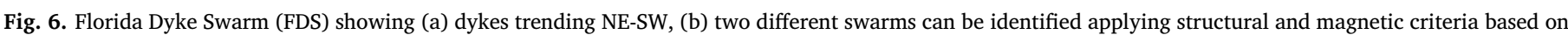

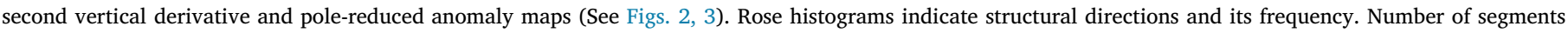

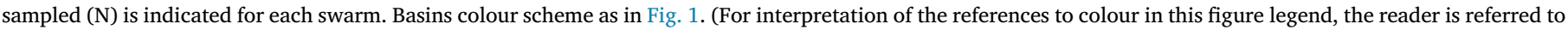
the web version of this article.)

Florida Dyke Swarm, as well as by the E-W and NW-SE Proterozoic structural fabric of the Piedra Alta Terrane (PAT) (Figs. 1, 2 and 4). The main normal faults trends coincide with the dykes strike.

Merín rift basin is bounded by $\mathrm{N} 70^{\circ} \mathrm{E}$ and $\mathrm{N} 110^{\circ} \mathrm{E}$ normal faults, and $\mathrm{N} 20^{\circ} \mathrm{E}$ strike-slip faults (Figs. 2, 4, 8). The N110 $\mathrm{E}$ faults follow the Nico Pérez-Zapicán Dyke Swarm (NZDS) structural trend, while the N70 ${ }^{\circ}$ E faults are concordant with its conjugate. Moreover, SSW-NNE Dom Feliciano Belt structures would control strike-slip dextral movements and facilitate structural accommodation (Figs. 8, 9), as previously suggested by Gómez Rifas (1995). The southern border of the Merín rift basin, would be given by a major northward dipping normal fault (the Aiguá Fault), corresponding to the conjugate direction of the Nico Pérez-Zapicán Dyke Swarm (Figs. 4, 8, 9). Together, these three directions controlled the development of the Merín rift basin. This pattern is consistent with the structural directions observed in the Euler solutions maps (Fig. 4). Meanwhile, basalts and ignimbrites dip $12^{\circ}$ northwards in this basin. Geological field evidence found in Salamanca, Lascano and Mariscala regions are consistent with these observations and interpretations (e.g. Cernuschi et al., 2015; Rossello et al., 2007; Gómez Rifas, 1995).

Both basins present a rhombohedral structuration controlled by different sets of faults. Merín rift basin is clearly controlled by three fault directions, the first related to the basement fabric $\left(\mathrm{N} 20^{\circ} \mathrm{E}\right)$, the second coincident with Nico Pérez-Zapicán Dyke Swarm trend (N110 ${ }^{\circ}$ E) and the third corresponding to its conjugate $\left(\mathrm{N70}{ }^{\circ} \mathrm{E}\right)$ (Figs. $\left.7,8,9\right)$. Santa Lucía rift basin is controlled by only two directions $\left(\mathrm{N}^{\circ} 0^{\circ} \mathrm{E}\right.$, $\mathrm{N} 144^{\circ} \mathrm{E}$ ), one almost parallel to the pre-existent structures in the Piedra Alta Terrane basement (dyke swarm and orogenic belts) and the other associated to the mesozoic rifting (Figs. 6, 7, 9).
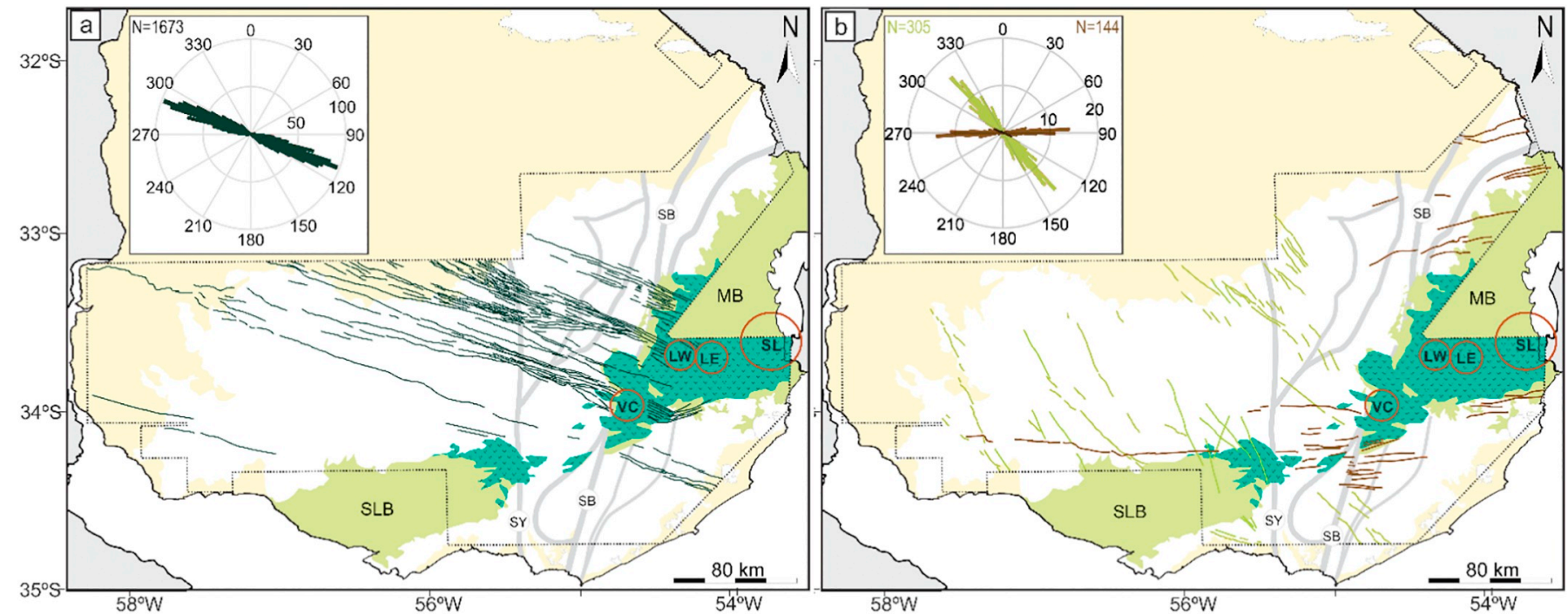

Fig. 7. (a) Nico Pérez-Zapican Mesozoic Dyke Swarm and sub-alkaline/alkaline intrusive centers shown as brown circles: Valle Chico (VC), Lascano East (LE), Lascano West (LW), San Luis (SL). (b) Secondary Mesozoic dyke Swarms. Rose histograms indicate structural directions and its frequency. Number of segments sampled (N) is indicated for each swarm. Basins colour scheme like in Fig. 1. Santa Lucia Basin (SLB), Merin Basin (MB), Sierra Ballena Shear Zone (SB), Sarandí del Yí Shear Zone (SY). Interpretation is based on the second vertical derivative and pole-reduced anomaly maps (See Figs. 2, 3). (For interpretation of the references to colour in this figure legend, the reader is referred to the web version of this article.) 


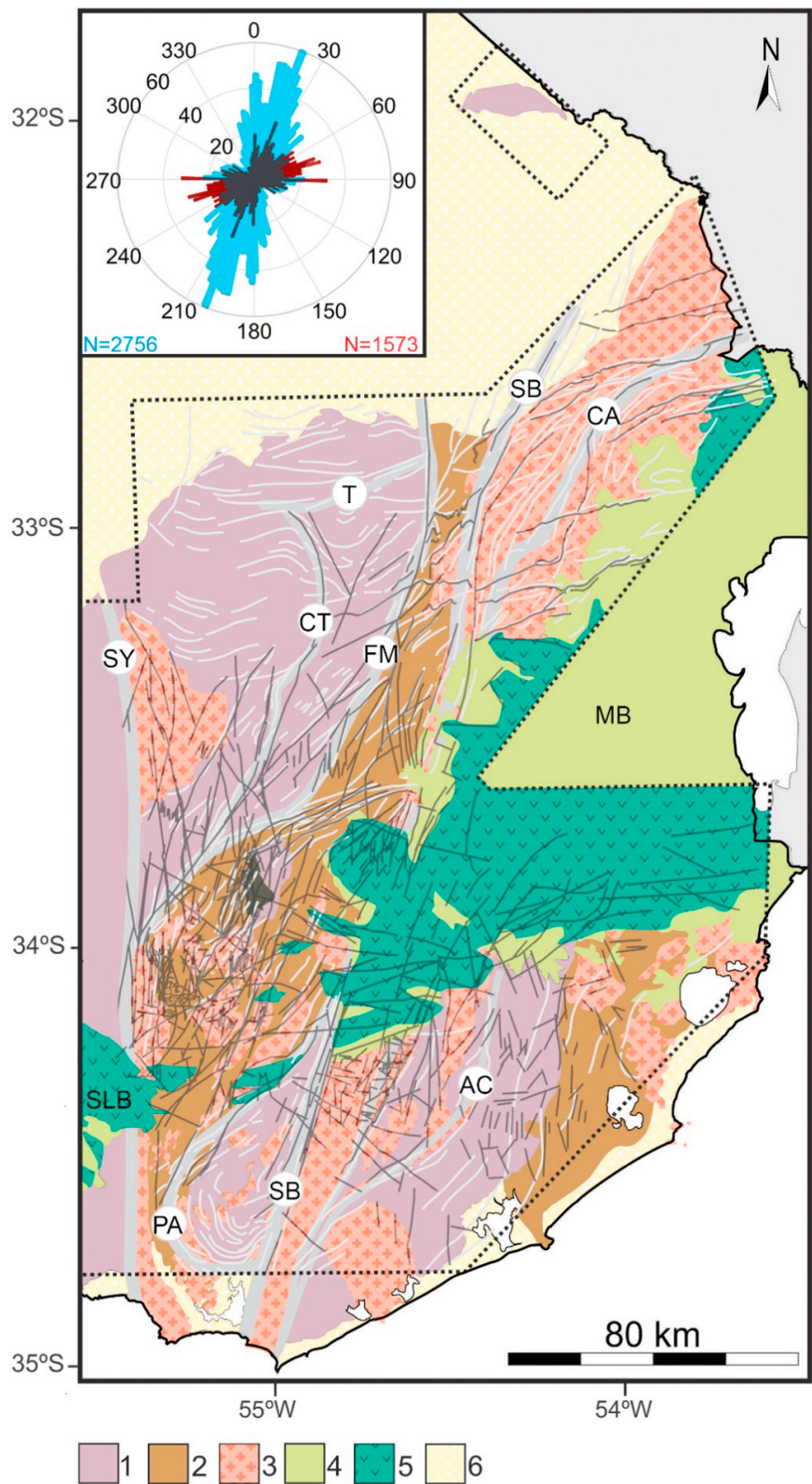

Fig. 8. Neoproterozoic structural trends defined through the analysis of the second vertical derivative of the anomaly map (Figs. 2, 3); (1) Archean to Paleoproterozoic Basement, (2) schist belts, (3) Meso- to Neo-Proterozoic granitoids, (4) Mesozoic rift basins, (5) Mesozoic igneous formations, (6) Phanerozoic basins. Light coloured lines indicate Proterozoic structural trends, black lines indicate main brittle structural trends observed in magnetic maps and aerial photographs. Rose histograms indicate brittle structural directions to the west (light blue) and east (dark red) of Sierra Ballena Shear Zone. Shear Zones: Sierra Ballena (SB), Sarandí del Yí (SY), Cueva del Tigre-Sierra de Sosa (CT), Fraile Muerto-Maria Albina (FM), Otazo-Cerro Amaro (CA), Alférez-Cordillera (AC), Tupambaé (T). (For interpretation of the references to colour in this figure legend, the reader is referred to the web version of this article.)

\subsection{Dom Feliciano Belt}

The structural trends observed in the aeromagnetic maps are consistent with studied and photointerpreted ductile and brittle structures previously documented in the Dom Feliciano Belt domain and related blocks (Preciozzi et al., 1979; Gómez Rifas, 1995; Masquelin, 2006; Sánchez Bettucci et al., 2010; Masquelin et al., 2017; among others). However, the central region located between both Mesozoic rift basins (among the Sarandí del Yí (SY) and Sierra Ballena (SB) shear zones) does not show evidence of general strike-slip movement along $\mathrm{N70}{ }^{\circ} \mathrm{E}$ trends, as previously suggested (Rossello et al., 1999, 2000, 2007).

Aeromagnetic maps show two main trends (NS and $\mathrm{N} 20^{\circ} \mathrm{E}$ ) dominate between the SY and Sierra Ballena (SB) shear zones, controlling brittle and ductile deformation (Fig. 8). These observed patterns in the aeromagnetic maps are consistent with the main structures of the Dom Feliciano Belt. Meanwhile, ca. N70 ${ }^{\circ} \mathrm{E}$ and EW trending magnetic lineaments dominate to the west of the Sarandí del Yí (SY) shear zone and to the east of the Sierra Ballena (SB) shear zone, being, NS and N20 E trends still present in lesser extent (Fig. 8).

Moreover, the aeromagnetic maps show dextral reactivation of $\mathrm{N} 20^{\circ}$ E faults (Dom Feliciano Belt structures) between the Sarandí del Yí (SY) and Sierra Ballena (SB) shear zones: (i) Nico Pérez-Zapicán Dyke Swarm appears to be displaced in dextral sense along Sierra Ballena (SB) Shear Zone, and inside Merín rift basin (MB) (Figs. 2, 7a, 9); (ii) other Mesozoic dyke swarms are also displaced in dextral sense along Sierra Ballena (SB) Shear Zone (Figs. 2, 7b, 9); (iii) Neoproterozoic granites (eg. Polanco Granitic Complex) also show dextral displacement along N20 $0^{\circ}$ E structures (Figs. 8, 9); (iv) Magnetic maps reveal that pull apart basins in this central region (Arequita (AB), Valle Fuentes (VFB), Tapes Sur (TSB) basins) are linked to ca. $\mathrm{N}^{\circ} 0^{\circ} \mathrm{E}$ faults, meanwhile Tapes Norte basin (TNB) is connected to the N36 ${ }^{\circ}$ E Soldado fault (Figs. 8, 9). The fault-graben geometry (Figs. 4, 8, 9) and fault dip direction determined through Euler analysis are consistent with releasing bend and pull-apart basins (see Aydin and Nur, 1982; Cunningham and Mann, 2007; Gürbüz, 2010) controlled by dextral strike-slip movements of the NE-SW faults.

Previous structural evidence also suggests accommodation and reactivation of blocks in the central area between the Santa Lucía (SB) and Merín (MB) rift basins (Gómez Rifas, 1995; Rossello et al., 2007; Núñez Demarco et al., 2018). Particularly, brittle deformation was found to be concentrated along the $\mathrm{N} 15^{\circ}-20^{\circ} \mathrm{E}$ trend parallel to Sierra Ballena (SB) Shear Zone (Gómez Rifas, 1995).

These evidences indicate that Dom Feliciano Belt structures acted as a barrier for the $\mathrm{N} 70^{\circ} \mathrm{E}$ and $\mathrm{EW}$ normal fault propagation, transferring deformation. Also, that the sinistral reactivation of NE-SW Neoproterozoic lineaments generated oblique and asymmetric hemigrabens, controlled by a curved northern listric fault with southward downthrow. Moreover, it suggests the occurrence of a clockwise rotation of the central block related to pre-existing basement structures, widely described in previous works (Gómez Rifas, 1989; Rossello et al., 2000, 2001, 2007, 2018; Masquelin et al., 2017). Areas to the south of the N36 ${ }^{\circ}$ E trending Soldado Fault (SF) are characterized by dextral $\mathrm{N} 45^{\circ} \mathrm{E}$ to $\mathrm{N} 10^{\circ} \mathrm{E}$ trending faults, which generate restricted pull apart basins (Fig. 9). Whereas, areas to the north of the N36 E Soldado Fault are characterized by sinistral $\mathrm{N} 20^{\circ} \mathrm{E}$ to $\mathrm{N} 10^{\circ} \mathrm{E}$ trending faults, which control compressive structures, like horsetails and strike-slip duplexes (Fig. 9). Such compressive structures are particularly observed in Barriga Negra Formation (BN, Fig. 9) (Núñez Demarco et al., 2019a), which is enclosed in a horse tail fault system (Fig. 9).

On the other hand, signs of reactivation of Sarandí del Yí (SY) Shear Zone are not detected (Figs. 2, 8).

\subsection{Euler deconvolution results - deep structure}

Euler solutions show that both main dyke swarms outcrop or are close to the surface, Euler depths ranging between 0 and $500 \mathrm{~m}$ (Fig. 4a), but commonly displaying deeper roots (Fig. 4c,d). Considering that uplift, exhumation and erosion affect our studied region, the interpretation of the depth to the top of the dykes is not possible. However, this fact contrasts with the limited field recognition of these dyke swarms due to the weathering and alteration of the craton (Bossi and Campal, 1991; Gómez Rifas, 1995; Teixeira et al., 1999; Halls et al., 2001; Núñez Demarco et al., 2013). Additionally, dips estimated through Euler deconvolution show that Florida Dyke Swarm presents a dip of $90^{\circ}$ to $60^{\circ}$ to the north. 


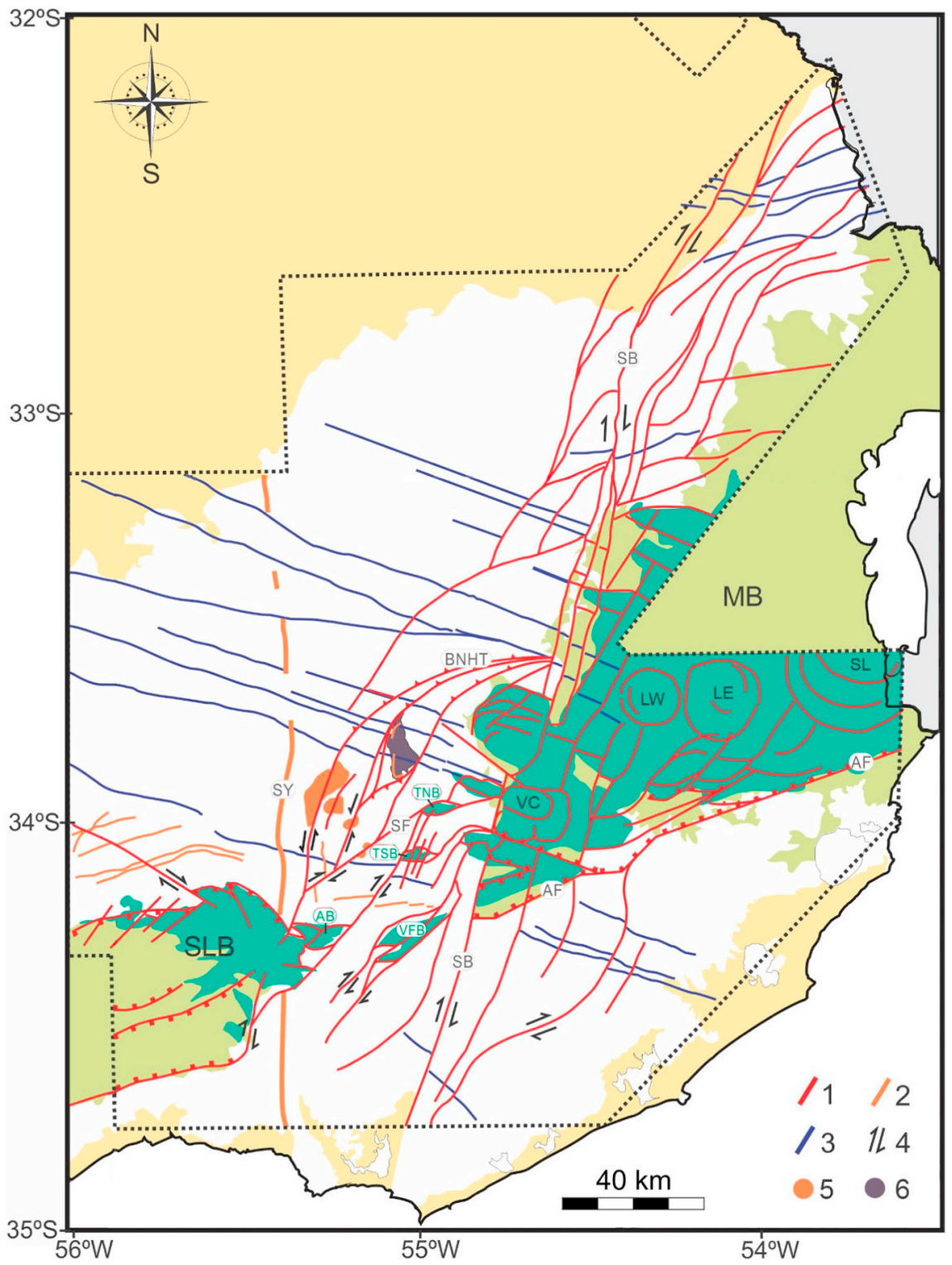

Fig. 9. Proposed tectonic model for the Mesozoic rift, with a transfer zone between the Santa Lucia (SLB) and Merín Basins (MB). (1) Main Mesozoic rift faults. (2) Proterozoic structural trends. (3) Mesozoic structural trends. (4) strike-slip faults movement directions, (5) Polanco Granitic Complex, (6) Barriga Negra Formation. Shear Zones: Sarandí del Yí (SY), Sierra Ballena (SB), Faults: Barriga Negra Horse Tail (BNHT), Soldado Fault (SF), Aiguá Fault (AF). Basins: Santa Lucia (SLB), Merín (MB), Arequita (AB), Valle Fuentes (VFB), Tapes Sur (TSB), Tapes Norte (TNB). Basins colour scheme as in Fig. 1. Intrusive centers: Valle Chico (VC), Lascano West (LW), Lascano East (LE), San Luis (SL).
On other hand, linear gaps (or steps) in the distribution of Euler solutions are observed in association with dyke trends (Fig. 4b-e). Euler solutions depict $\mathrm{N} 70^{\circ} \mathrm{E}$ and $\mathrm{N} 120^{\circ} \mathrm{E}$ striking structures, which crosscut with a rhombohedral pattern the Uruguayan basement (Fig. 4). Such pattern coincides with main fault trends in the Mesozoic rift basins. The $\mathrm{N} 120^{\circ} \mathrm{E}$ solutions alignments are constituted by magnetic deep sources, which reach depths of up to $5 \mathrm{~km}$. On the other hand, the $N 70^{\circ} \mathrm{E}$ alignments are characterized by an abrupt absence of Euler solutions at depths larger than $500 \mathrm{~m}$ (Fig. 4c). Some of these solutions alignments are related to well-known faults, like Aiguá normal fault in the southern border of the Merín rift basin (MB), suggesting that these gaps in Euler solutions reflect faults and vertical block movements (Fig. 4e). Moreover, Euler solutions show a structural relationship and continuity between the southern border of the Merín rift basin, represented by the northward dipping Aiguá fault (AF), and the central fault of the Santa Lucia (SLB) rift basin (Figs. 4, 9), represented by a southward dipping horst fault (Veroslavsky et al., 2006). This indicates that the fault and basin polarity is inverted, suggesting a transference region between the two basins (Fig. 9).

Additionally, the distribution of Euler solutions shows that one prominent structure parallel to the rift axis would be located $40 \mathrm{~km}$ to the north of the known rift limit (Fig. 4). This structure can be interpreted as a fault or basement step, and could indicate that the northern border of the Santa Lucia rift basin (SLB) could be located approximately $40 \mathrm{~km}$ to the north of the actually proposed basin limit (Figs. 4, 9).

Furthermore, clusters of Euler solutions coincide with well-known shear zones and structural limits. Sierra Ballena (SB) and Otazo-Cerro Amaro (CA) Shear Zones represent one of the main magnetic lineaments (Figs. 1, 2, 4), suggesting that they would correspond to one of the major deep-rooted structures. Strikingly, to the north, Otazo-Cerro Amaro (CA) Shear Zone appears to be a structure with major significance than the northern portion of the Sierra Ballena (SB) Shear Zone. The recent identification of ophiolites along Otazo-Cerro Amaro (CA) Shear Zone supports this interpretation (Peel et al., 2018). In addition, the Sarandí del Yí (SY) Shear Zone is not well represented by a distinct distribution and/or clustering of Euler solutions at depth (Fig. 4). This last fact could suggest that it does not correspond to a deep-rooted structure. This observation is consistent with magnetotelluric data presented by (Bologna et al., 2019), which also fail in detecting this structure in depth. 


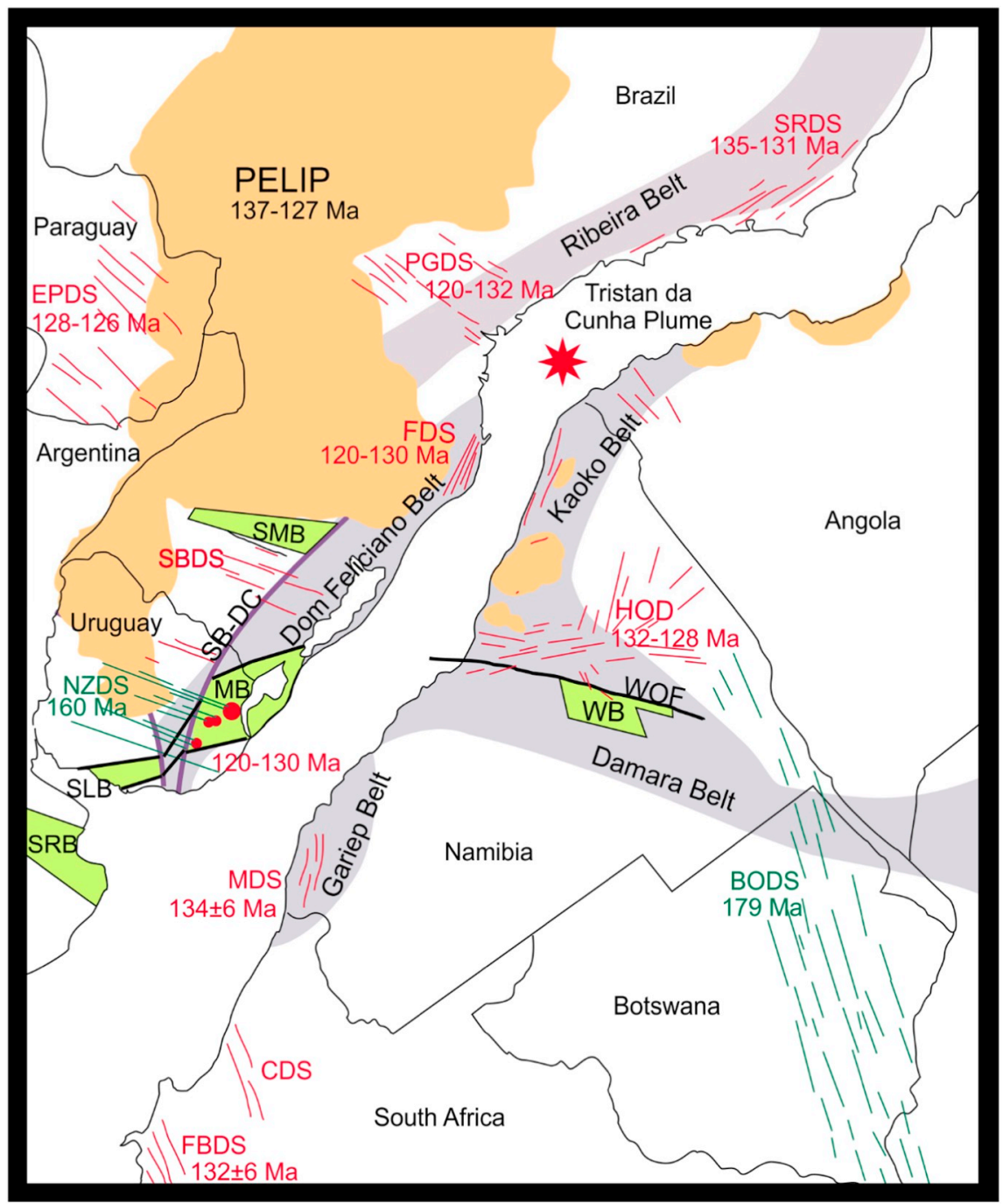

Fig. 10. Distribution of flood basalts and dyke swarms in a pre-drift reconstruction of South America and Africa, and their relative ages. Nico Pérez-Zapicán Dyke Swarm (NZDS), South Brazil Dyke Swarm (SBDS), Ponta Grossa Dyke Swarm (PGDS), Eastern Paraguay Dyke Swarm (EPDS), Florianopilis Dyke Swarm (FDS), Santos-Rio de Janeiro Dyke Swarm (SRDS), Henjes Bay-Outjo Dike Swarm (HOD), Botswana-Okavango Dyke Swarm (BODS), Mehlberg Dyke Swarm (MDS), Cedarberg Dyke Swarm (CDS), False Bay Dyke Swarm (FBDS). Santa Maria Rift Basin (SMB), Santa Lucia Rift Basin (SLB), Merín Rift Basin (MB), Waterberg Rift Basin (WB), Salado Rift Basin (SRB), Parana-Etendeka Large Igneous Province (PELIP) Waterberg-Omaruru Fault system (WOF), Sierra Ballena- Dorsal de Canguçú Shear Zone System (SB-DC). Based on Zerfass et al. (2005), Strugale et al. (2007), Masquelin et al. (2009), Will and Frimmel (2013), Florisbal et al. (2014), Cernuschi et al. (2015), Salomon et al. (2017).

\section{Discussion}

\subsection{Florida Dyke Swarm}

Florida Dyke Swarm (FDS) would be larger, denser and more widespread than previously documented (Fig. 6, Bossi et al., 1993b; Teixeira et al., 2002, 2013; Halls et al., 2001). This Paleoproterozoic dyke swarm has been related to an incipient extensional event (aborted rift) younger than the orogenic events that previously affected the Piedra Alta Terrane (PAT), according to their geochronology and nonorogenic signatures (Bossi et al., 1993b; Halls et al., 2001; Teixeira et al., 2002, 2013; Girardi et al., 2013). Based on geochemical analyses (Bossi et al., 1993b; Mazzucchelli et al., 1995; Girardi et al., 2013) proposed three possible and indistinguishable sources of crustal contamination for the Florida Dyke Swarm (FDS): a) the introduction of sedimentary components during a previous subduction; b) a non-subduction-related metasomatism; c) melting of the sub-lithospheric mantle and dehydration of underplated oceanic crust under the effects of a plume. The observed dimensions of the Florida Dyke Swarm (FDS) are consistent with giant dyke swarms, and a more "widespread" extensional event, probably associated to mantle plumes, considering the chemical characteristics of the swarm (see Ernst and Buchan, 2001). Additionally, radial dyke swarms maintain a subvertical, straighter and/or parallel behaviour farther from the magmatic source, generally controlled by regional stress, but curve to a radial disposition and tilt towards the center near the magmatic source (Jolly and Sanderson,
1995; Aïfa et al., 1999; Hou et al., 2010). Florida Dyke Swarm (FDS) has a straight and parallel disposition but it presents a gentle northward flexure (at the north of the studied area) and a general tilt to the north, decreasing its dip according to Euler results (Fig. 4). These evidences could suggest that the magmatic source (mantle plume) was located towards the current northeastern border of the Piedra Alta Terrane. Moreover, the flexure and location of this dyke swarm near a terrain margin (Sarandí del Yí (SY) Shear Zone see Oyhantçabal et al., 2010; Sánchez Bettucci et al., 2010; Rapela et al., 2007) is also a diagnostic signature of a giant radial swarm originated by a mantle plume (Ernst and Buchan, 2001; Bleeker and Ernst, 2006). This mantle plume origin could be a fundamental clue that could aid to overcome paleomagnetic reconstructions uncertainties during the Paleoproterozoic, using geometrical matching of giant dyke swarms (Bleeker and Ernst, 2006). Alternatively, it could indicate the presence of a new undiscovered dextral shear zone in the northern region of Piedra Alta Terrane (PAT).

In addition, the fact that in the Piedra Alta Terrane (PAT) the mafic dyke swarms are almost undeformed, supports the purported cratonic stability since Staterian times (Paleoproterozoic) (Bossi et al., 1993a; Mazzucchelli et al., 1995; Bologna et al., 2019).

\subsection{Mesozoic rift dimensions}

The aeromagnetic map of Uruguay reveals that the area affected by Mesozoic rifting would be wider than previously proposed (Rossello et al., 1999, 2000, 2007, 2018; Hueck et al., 2017). The width of the 
Santa Lucía-Merín aulacogenic basins is similar to the one of the Okavango (Southern Africa), Tanganyka (East Africa) and Baikal (Asia) rifts. Okavango rift basins are $40-100 \mathrm{~km}$ wide, have $<100 \mathrm{~m}$ of relief and are filled by $<600 \mathrm{~m}$ of sediments (Modisi et al., 2000). Tanganyka and Baikal rifts have a relief of $>1000 \mathrm{~m}$ and a sedimentary infill thickness of 1-8 km (e.g., Ebinger, 1989; Logatchev, 1993; Lezzar et al., 1996). This evidence supports the theory proposed by Modisi et al. (2000), who state that the width of continental rifts is probably acquired very early during their evolution and does not necessarily reflect the age of the rift basins. They suggest that the amount of downthrow and the thickness of sedimentary infill are better indicators of the maturity of continental rift basins.

\subsection{Mesozoic rifting mechanics}

The aeromagnetic data and Euler deconvolution results suggest that the apparent rhombohedral geometry of Santa Lucía (SLB) and Merín (MB) rift basins is related to the main conjugate faults, rather than the consequence of pull apart tectonics controlled by only one $\mathrm{N} 70^{\circ} \mathrm{E}$ strikeslip fault, as was previously suggested (Rossello et al., 2000, 2007, 2018; Veroslavsky et al., 2006). Although, Merín (MB) rift basin exhibits a more complex triangular structuration, with two faults directions that can be associated to inherited basement structures, and one $\mathrm{N} 110^{\circ} \mathrm{E}$ fault developed during the first extensional stages of the rift (Figs. 8, 9).

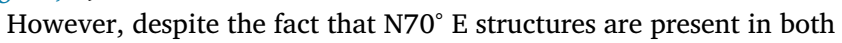
basins, the observed magnetic patterns are not consistent with the occurrence of strike-slip movements along this direction nor with the existence of a dextral $\mathrm{N} 70^{\circ} \mathrm{E}$ strike-slip pull-apart basin geometry (see Aydin and Nur, 1982; Cunningham and Mann, 2007; Gürbüz, 2010). Previous models suggested that strike-slip tectonics represented a major deformational component during the earliest stages of the Uruguayan rifting. In fact, the Mesozoic rift was defined as a $N 70^{\circ} \mathrm{E}$ trending tectonic corridor (sic) with dextral movements, along which Santa Lucia (SLB) and Merín (MB) rift basins developed as pull-apart structures (Rossello et al., 2000, 2007, 2018; Veroslavsky et al., 2006).

Magnetic interpretations show clearly that Sarandí del Yí (SY) and Sierra Ballena (SB) Shear Zones, and blocks between Santa Lucia (SLB) and Merín (MB) rift basins, exhibit no major evidence of strike-slip faulting along the proposed $N 70^{\circ} \mathrm{E}$ trend. $\mathrm{N70^{ \circ }} \mathrm{E}$ structures did not propagate between Sarandí del Yí (SY) and Sierra Ballena (SB) Shear Zones (Fig. 6). The Nico Pérez-Zapicán Dyke Swarm is displaced by Sierra Ballena (SB) Shear Zone, indicating brittle reactivation and accommodation of the deformation.

Moreover, structural analysis, aeromagnetic maps interpretation and Euler deconvolution results, not only show that the major deeprooted Sierra Ballena (SB) ductile shear zone acted like a barrier to the longitudinal propagation of the Mesozoic rift (as was noticed in previous works, e.g. Hueck et al., 2017), but also accommodated a huge amount of deformation along its structure, conversely to previous interpretations (Hueck et al., 2017). In addition, all Neoproterozoic structures acted as a barrier, hindering the propagation of $\mathrm{N70} 0^{\circ} \mathrm{E}$ striking faults, in contradiction with the current model that proposes a continuous rift with dextral shear along the $\mathrm{N}^{\circ} 0^{\circ} \mathrm{E}$ direction (Rossello et al., 2000, 2001, 2007, 2018; Veroslavsky et al., 2006). In fact, previous works (Gómez Rifas, 1995; Rossello et al., 2007) and the new data here presented support that Mesozoic normal and strike-slip faults, in this central region, are linked to reactivations of Neoproterozoic NS$\mathrm{N} 20^{\circ} \mathrm{E}$ faults and shear zones, and not to the $\mathrm{N} 70^{\circ} \mathrm{E}$ trend.

Furthermore, the Mesozoic rift was constructed not only reactivating ancient faults but also creating new ones. The Nico PérezZapicán Dyke Swarm does not follow any known preexisting structural trend, but crosscuts them obliquely.

Considering the new evidence discussed in this work, we propose that the intermediate block between Merín and Santa Lucia rift basins (between the two major shear zones in Uruguay) acted as an accommodation or transfer zone with a complex transpressive structural pattern, connecting the adjacent grabens, and following the main fault pattern identified in magnetic maps (Figs. 2, 7, 8, 9). According to Euler deconvolution, a fault inversion could connect the southern border of the Merín (MB) rift basin with the central faults of the Santa Lucia (SLB) rift basin through the transfer zone, representing the main fault that initiated the rift evolution (Figs. 4e, 9). This kind of border was identified in other rifts of the world, were shear zones acted as barriers for the propagation of rifts when transferring the deformation (Modisi et al., 2000; Kinabo et al., 2007; Zerfass et al., 2005; Salomon et al., 2015a, 2015b).

Previous works also interpreted the relative elevation of the Nico Pérez Terrane (NPT) and Dom Feliciano Belt as the consequence of the uplift of this central region (Rossello et al., 2000, 2007, 2018; Hueck et al., 2017). However, topographic differences can be better explained considering that (i) the rift is wider than previously thought, (ii) the central region was preserved from extension and rifting due to accommodation mechanics, and (iii) the geometry of transfer zones is one of the major controls in drainage and basin infill (Gawthorpe and Hurst, 1993; Morley et al., 1990). This explanation is more parsimonious and does not demand the action of other events.

Mesozoic reactivation of the Kaoko (Fig. 10) and Dom Feliciano Belts was previously suggested by Zerfass et al. (2005), although substantial evidence of reactivation of Dom Feliciano Shear Zones was considered lacking until now (Salomon et al., 2015a, 2015b, 2017). Transfer zones geometry and topography exert a fundamental influence in basin development and stratigraphy of the graben-fill, and may have either a positive or a negative effect in aquifers and hydrocarbon entrapment in rift systems (Gawthorpe and Hurst, 1993; Morley et al., 1990). The recognition of a transfer zone in the Uruguayan Basement opens new possibilities for interpretation and study of the Uruguayan rift basins.

\subsection{Age constraints and regional correlation}

Nico Pérez-Zapicán Dyke Swarm, considered by Lossada et al. (2014) as Upper Jurassic based on ${ }^{40} \mathrm{Ar}-{ }^{39} \mathrm{Ar}$ and paleomagnetic data (ca.160 Ma), crosscuts all preexisting pre-Mesozoic structures, like the Dom Feliciano Belt and the Florida Dyke Swarm (FDS), and is connected to the Mesozoic volcanic centres (see Fig. 7a). Curiously, this dyke swarm system has a strike $\left(\mathrm{N} 110^{\circ} \mathrm{E}\right)$ consistent with the South American branch of the Waterberg-Omaruru fault system (WOF) (Namibia), which is related to the Waterberg rift basin (WB) (Early Triassic to Early Jurassic) and to the Santa Maria rift basin (SMB) (Middle Triassic to Early Jurassic) that developed before the South Atlantic Opening (Zerfass et al., 2005) (Fig. 10).

However, aeromagnetic maps show that Nico Pérez-Zapicán Dyke Swarm (NZDS) was not blocked, but slightly deflected by shear zones and was affected by dextral strike-slip tectonics along reactivated preexisting structures in the Dom Feliciano Belt. This is particularly evident along the Sierra Ballena (SB) and Alférez-Cordillera (AC) Shear Zones (Figs. 2, 7, 9, 10). Reactivation of Dom Feliciano Belt structures was also suggested by Zerfass et al. (2005), during Middle Triassic to Early Jurassic, when this belt also acted as a transfer zone between Waterberg (WB) rift basin in Africa and Santa Maria rift basin (SMB) in América (Fig. 10). In Uruguay, rift basins developed since Late Jurassic (Veroslavsky et al., 2006), but also in apparent continuation to Waterberg-Omaruru fault system (WOF). Although, Merín rift basin (MB) developed over the Punta del Este Terrane (with African affinities) and the Santa Lucia rift basin (SLB) over the Piedra Alta Terrane (PAT) (Río de la Plata Craton) with the Dom Feliciano Belt also acting as a transfer zone (Figs. 9, 10).

The last stages of rift evolution are coincident with the youngest volcanic events in the area, which correspond to the extrusion of the Valle Chico, Lascano and San Luis magmatism between 120 and $130 \mathrm{Ma}$ (Early Cretaceous) (Fig. 7a, Cernuschi et al., 2015). These volcanic 
centers appear to be directly related to the Nico Pérez-Zapicán Dyke Swarm (NZDS), suggesting a reactivation of the same fault system. Moreover, the orientation of Nico Pérez-Zapicán Dyke Swarm (NZDS), with Late Jurassic ages, coincides with orientations documented in Uruguay (N110-120 E, $132 \mathrm{Ma}$, Masquelin et al., 2009), Southern Brazil Dyke Swarm (SBDS) (Salomon et al., 2017), Ponta Grossa Dyke Swarm (PGDS) in Brazil (N135 E, 120-132 Ma, Renne et al., 1996, Strugale et al., 2007) and Eastern Paraguay Dyke Swarm (EPDS) (N135 E, 128-126 Ma, Druecker and Gay Jr, 1987; Comin-Chiaramonti et al., 1999), covering thousands of square kilometres (See Fig. 10). This giant dyke swarm is considered the feeder dyke system of the Parana-Etendeka Large Igneous Province (PELIP) (137 Ma - $127 \mathrm{Ma}$ ), and associated to the Tristan da Cunha hotspot (Ernst and Buchan, 2001; Salomon et al., 2017). This could suggest a continuation and general reactivation of the Waterberg-Omaruru Fault system (WOF) in América and Africa (Zerfass et al., 2005) (Fig. 10). Furthermore, a second dyke swarm, that crosscut the rift basins, has also compatible strikes (N144 ${ }^{\circ}$ E, Fig. 7 b) with a late fault system developed in Southern Brazil during Early Cretaceous times, in response to the proto-oceanic phase of the South Atlantic (Zerfass et al., 2005).

In consequence, we suggest that the Mesozoic rift evolution in Uruguay is characterized by the occurrence of three volcanic and extensional events, constrained between 157 and 120 Ma (Late Jurassic to Early Cretaceous).

\section{Conclusions}

The new high-resolution aeromagnetic data from the Uruguayan Shield allowed the identification of four main magnetic morphostructural units: the Paleoproterozoic Florida Dyke Swarm $\left(\mathrm{N}^{\circ} \mathrm{E}\right.$ trend); the Dom Feliciano Belt (N0-20 $\mathrm{E}$ trend), the Mesozoic Nico Pérez-Zapicán Dyke Swarm (N110 $\mathrm{E}$ trend), and the Mesozoic Rift Basins.

Our analysis provides new criteria to identify different dyke swarms based on structural and magnetic patterns, recognizing four new minor dyke swarms, two related to the Florida Dyke Swarm with $N 78^{\circ} \mathrm{E}$ and $\mathrm{N} 54^{\circ}$ E structural trends, and two related to the Mesozoic extensional events with trending $\mathrm{N} 89^{\circ} \mathrm{E}$ and $\mathrm{N} 144^{\circ} \mathrm{E}$, respectively.

Spatial distribution, dimension, geometrical relationships with the border of the Piedra Alta Terrane and geochemical characteristics of the Paleoproterozoic swarm, could indicate a mantle plume origin.

There are clear spatial relationships between Mesozoic dyke swarms, feeder dykes and plutonic bodies. These swarms crosscut the inherited basement structures, but are affected by Mesozoic dextral reactivation of NNE-SSW and ENE-WSW neoproterozoic strike-slip faults. Available geochronological data and cross-cut relationships suggest that Mesozoic dyke swarms represent the first and last extensional stages, that successively reactivated the same crustal zones of weakness.

The central region located between Santa Lucia - Merín rift basins (between Sarandí del Yí (SY) and Sierra Ballena (SB) Shear Zones) worked as a transfer zone through the preexisting NE-SW and N-S Dom Feliciano Belt structures. The major shear zones (SY and mainly SB Shear Zones) represent main barriers during rift propagation, evolving into accommodation or transfer zones during rift evolution.

\section{CRediT authorship contribution statement}

Pablo Nuñez Demarco: Conceptualization, Methodology, Software, Formal analysis, Data curation, Writing - original draft. Henri Masquelin: Conceptualization, Methodology, Investigation, Writing - original draft. Claudia Prezzi: Conceptualization, Methodology, Supervision, Writing - review \& editing. Tahar Aifa: Supervision. Rossana Muzio: Investigation, Writing - review \& editing. Judith Loureiro: Investigation, Writing - review \& editing. Elena Peel: Investigation, Writing - review \& editing. Nestor
Campal: Supervision, Project administration. Leda Sánchez Bettucci: Supervision, Project administration, Writing - review \& editing.

\section{Acknowledgements}

We would like to thank to Tahar Aifa of the Univ. Rennes (France) for their valuable contributions to this paper. We also appreciate the help given by CONICET (Argentina) for the granting of the Doctoral Scholarship of Pablo Núñez. This work is part of the Universidad de la Republica (FCIEN)- Ministerio de Industria y Energía (DINAMIGE) convention, and it would not have been possible without the collaboration of the Dirección Nacional de Minería y Geología.

\section{Declaration of competing interest}

The authors declare that they have no known competing financial interests or personal relationships that could have appeared to influence the work reported in this paper.

\section{References}

Aïa, T., Lefort, J.P., Guennoc, P., 1999. Anisotropy of magnetic susceptibility investigations of the St Malo dyke swarm (Brittany, France): emplacement mechanism of doleritic intrusions. Geophys. J. Int. 139 (2), 573-582.

Amar, N., Khattach, D., Azdimousa, A., Chourak, M., Jabaloy, A., Manar, A., Amar, M., 2015. Structure and peridotite of Gibraltar arc southern bloc: gravimetric and aeromagnetic evidences. Arab. J. Geosci. 8 (11), 9801-9813.

Anderson, E.M., 1951. The Dynamics of Faulting and Dyke Formation with Applications to Britain. Hafner Pub. Co.

Ansari, A.H., Alamdar, K., 2009. Reduction to the pole of magnetic anomalies using analytic signal. World Appl. Sci. J. 7 (4), 405-409.

Archibald, N., Gow, P., Bochetti, F., 1999. Multiscale edge analysis of potential field data. Explor. Geophys. 30, 38-44. https://doi.org/10.1071/EG999038.

Aydin, A., Nur, A., 1982. Evolution of pull-apart basins and their scale independence. Tectonics 1 (1), 91-105.

Baranov, V., 1957. A new method for interpretation of aeromagnetic maps: pseudogravimetric anomalies. Geophysics 22 (2), 359-382.

Baranov, V., Naudy, H., 1964. Numerical calculation of the formula of reduction to the magnetic pole. Geophysics 29, 67-79.

Basei, M.A.S., Teixeira, W., 1987. Geocronologia do Pré-Cambriano/Eopaleozóico de Santa Catarina. In: Silva, L.A., Bertoluzzi, C.A. (Eds.), Texto Explicativo para o Mapa Geológico do Estado de Santa Catarina - 1:500.000. 3. DNPM/CPRM, Florianópolis, pp. 91-130.

Basei, M.A.S., Siga Jr., O., Masquelin, H., Harara, O.M., Reis Neto, J.M., Preciozzi, F, 2000. The Dom Feliciano Belt (Brazil-Uruguay) and its foreland (Río de la Plata Craton): Framework, Tectonic evolution and correlations with similar terranes of Southwestern Africa. In: Cordani, T.F., Milani (Eds.), Precambrian Evolution of South America. Intern. Geological Congress - IUGS, Rio de Janeiro.

Basei, M.A.S., Frimmel, H.E., Nutman, A.P., Preciozzi, F., Jacob, J., 2005. A connection between the Neoproterozoic Dom Feliciano (Brazil/Uruguay) and Gariep (Namibia/ South Africa) orogenic belts-evidence from a reconnaissance provenance study. Precambrian Res. 139 (3-4), 195-221.

Basei, M.A.S., Frimmel, H.E., Nutman, A.P., Preciozzi, F., 2008. West Gondwana amalgamation based on detrital zircon ages from Neoproterozoic Ribeira and Dom Feliciano belts of South America and comparison with coeval sequences from SW Africa. Geol. Soc. Lond., Spec. Publ. 294 (1), 239-256.

Basei, M.A., Peel, E., Bettucci, L.S., Preciozzi, F., Nutman, A.P., 2011. The basement of the Punta del Este Terrane (Uruguay): an African Mesoproterozoic fragment at the eastern border of the South American Río de la Plata craton. Int. J. Earth Sci. 100 (2-3), 289-304.

Bellieni, G., Comin-Chiaramonti, P., Marques, L.S., Melfi, A.J., Nardy, A.J.R., Papatrechas, C., 1986. Petrogenetic aspects of acid and basaltic lavas from the Paraná plateau (Brazil): geological, mineralogical and petrochemical relationships. J. Petrol. 27 (4), 915-944.

Bleeker, W., Ernst, R., 2006. Short-Lived Mantle Generated Magmatic Events and their Dyke Swarms: The Key Unlocking Earth's Paleogeographic Record Back to 2.6 Ga. Dyke Swarms-Time Markers of Crustal Evolution. pp. 3-26.

Bologna, M.S., Dragone, G.N., Muzio, R., Peel, E., Nuñez-Demarco, P., Ussami, N., 2019. Electrical structure of the lithosphere from Rio de la Plata Craton to Paraná Basin: amalgamation of cratonic and refertilized lithospheres in SW Gondwanaland. Tectonics 38 (1), 77-94.

Bossi, J., 1966. Geología del Uruguay. UdelaR, Publicaciones (469pp).

Bossi, J., Campal, N., 1991. Granitos Negros Filonianos del Uruguay: Resultados de las investigaciones. Agreement CIID-IDRC - UdelaR, Project N 90650. (Final Report, Ottawa, Canada. 72pp).

Bossi, J., Campal, N., 1992. Magmatismo y tectónica transcurrente durante el Paleozoico Inferior en Uruguay. In: Gutiérrez Marco, J.G., Saavedra, J., Rábano, J. (Eds.), Paleozoico Inferior de Ibero-América. Univ. de Extremadura, Spain, pp. 343-356 
Chp. 17.

Bossi, J., Cingolani, C., 2009. Extension and general evolution of the Río de la Plata Craton. Developments in Precambrian Geology 16, 73-85.

Bossi, J., Navarro, R., 1991. Geología del Uruguay. Universidad de la República, Montevideo (970 pp).

Bossi, J., Campal, N., Preciozzi, F., 1993a. Predevoniano del Uruguay: Parte I: Terreno Piedra Alta. Montevideo: Dirección Nacional de Minería y Geología. (50pp).

Bossi, J., Campal, N., Civetta, L., Demarchi, G., Girardi, V.A.V., Mazzucchelli, M., Teixeira, W., 1993b. Early Proterozoic dike swarms from western Uruguay: geochemistry, Sr Nd isotopes and petrogenesis. Chem. Geol. 106 (3-4), 263-277.

Bossi, J., Ferrando, L., Montaña, J., Campal, N., Morales, H., Gancio, F., Schipilov, A., Piñeyro, D., Sprechmann, P., 2001. Memoria explicativa de la Carta Geológica del Uruguay a escala 1:500.000, UdelaR - Fac. Agronomía.

Bournas, N., Galdeano, A., Hamoudi, M., Baker, H., 2003. Interpretation of the aeromagnetic map of Eastern Hoggar (Algeria) using the Euler deconvolution, analytic signal and local wavenumber methods. J. Afr. Earth Sci. 37 (3-4), 191-205.

Bryan, S.E., Ernst, R.E., 2008. Revised definition of large igneous provinces (LIPs). Earth Sci. Rev. 86 (1-4), 175-202.

Burke, K., Dewey, J.F., 1973. Plume-generated triple junctions: key indicators in applying plate tectonics to old rocks. The Journal of Geology 81 (4), 406-433.

Cernuschi, F., Dilles, J.H., Kent, A.J.R., Schroer, G., Raab, A.K., Conti, B., Muzio, R., 2015. Geology, geochemistry and geochronology of the Cretaceous Lascano East Intrusive Complex and magmatic evolution of the Laguna Merín Basin, Uruguay. Gondwana Res. 28 (2), 837-857.

Cervantes-Solano, M., Sánchez Bettucci, L., Gogorza, C., Goguitchaichvili, A., MoralesContreras, J.J., Rapalini, A., 2017. Nuevo estudio paleomagnético y de magnetismo de rocas realizado en el Enjambre de diques básicos de Nico Pérez-Zapicán, Uruguay. In: Proceedings, Juriquilla, Queretaro, Mexico. Volume 7. Latinmag Letters, pp. 1-6 Special Issue, PM01.

Chen, Q., Dong, Y., Cheng, S., Han, L., Xu, H.H., Chen, H., 2014. Interpretation of fault system in the Tana Sag, Kenya, using edge recognition techniques and Euler deconvolution. J. Appl. Geophys. 109, 150-161.

Coffin, M.F., Eldholm, O., 1994. Large igneous provinces: crustal structure, dimensions, and external consequences. Rev. Geophys. 32 (1), 1-36.

Comin-Chiaramonti, P., Cundari, A., DeGraff, J.M., Gomes, C.B., Piccirillo, E.M., 1999. Early Cretaceous-Tertiary magmatism in Eastern Paraguay (western Paraná basin): geological, geophysical and geochemical relationships. J. Geodyn. 28 (4-5), 375-391.

Conti, B., 2008. Caracterización faciológica y estructural del magmatismo Mesozoico en la región de Lascano (Undergraduate thesis). Facultad de Ciencias, UDELAR, Montevideo (85 pp).

Creixell, C., Parada, M., Morata, D., Vásquez, P., Pérez de Arce, C., Arriagada, C., 2011. Middle-Late Jurassic to Early Cretaceous transtension and transpression during arc building in Central Chile: evidence from mafic dike swarms. Andean Geol. 38 (1), $37-63$.

Cunningham, W.D., Mann, P., 2007. Tectonics of strike-slip restraining and releasing bends. Geol. Soc. Lond., Spec. Publ. 290 (1), 1-12.

De Santa Ana, H., Goso, C., Muzio, R., Oyhantçabal, P., Veroslavsky, G., 1994. Bacia do Santa Lucia (Uruguai): evoluçaõ tectônica e sedimentar. Geociências (Brasilia) 13 (1), $37-52$.

de Castro Valente, S., Corval, A., Duarte, B.P., Ellam, R.M., Fallick, A.E., Meighan, I.G. Dutra, T., 2007. Tectonic boundaries, crustal weakness zones and plume-subcontinental lithospheric mantle interactions in the Serra do Mar dyke swarm, SE Brazil. Brazilian Journal of Geology 37 (1), 194-201.

Dentith, M., Mudge, S., 2014. Geophysics for the Mineral Exploration Geoscientist. Cambridge University Press (438pp)

Druecker, M.D., Gay Jr., S.P., 1987. Mafic Dyke Swarms Associated with Mesozoic Rifting in Eastern Paraguay, South America. Mafic Dyke Swarms. 34. Geological Association of Canada, Special Publication, pp. 187-193.

Durr, S.B., Dingeldey, D.P., 1996. The Kaoko belt (Namibia): part of a late Neoproterozoic continental-scale strike-slip system. Geology 24 (6), 503-506.

Ebinger, C.J., 1989. Geometric and kinematic development of border faults and accommodation zones, Kivu-Rusizi rift, Africa. Tectonics 8 (1), 117-133.

Elkins, T.A., 1951. The second derivative method of gravity interpretation. Geophysics 16 (1), 29-50.

Ernst, R.E., 2014. Large igneous provinces. Cambridge University Press, Cambridge (666 pp).

Ernst, R.E., Buchan, K.L., 1997. Giant radiating dyke swarms: their use in identifying preMesozoic large igneous provinces and mantle plumes. In: Large Igneous Provinces: Continental, Oceanic, and Planetary Flood Volcanism. AGU Geophys. Monograph 100. pp. 297-333.

Ernst, R.E., Buchan, K.L., 2001. The use of mafic dike swarms in identifying and locating mantle plumes. In: Ernst, R.E., Buchan, K.L. (Eds.), 2001 Mantle Plumes: Their Identification through Time. 352. pp. 247.

Ernst, R.E., Buchan, M.L., West, T.D., Palmer, H.C., 1996. Diabase (Dolerite) Dyke Swarms of the World, 1st ed. Geological Survey of Canada (Open File 3241).

Escher, A., Escher, J.C., Watterson, J., 1975. The reorientation of the Kangâmiut dike swarm, West Greenland. Can. J. Earth Sci. 12 (2), 158-173.

Fedi, M., Pilkington, M., 2012. Understanding imaging methods for potential field data. Geophysics 77 (1), G13-G24.

Fernandes, L.A.D., Tommasi, A., Porcher, C., 1992. Deformation patterns in the southern brazilian branch of the Dom Feliciano Belt: a reappraisal. J. S. Am. Earth Sci. 5 (1), 77-96.

Fernandes, L.A.D., Milani, E.J., Menegat, R., Faccini, U.F., Caravaca, G., Oliveira, J.M.M.T., Veigel, R., Vignol-Lelarge, M.L.M., Bachi, F.A., Scherer, C.M.S., 1995. Evolução do sistema de zonas de cisalhamento transcorrentes Dorsal de Canguçú durante o Fanerozóico. In: Simpósio Nacional de Estudos Tectônicos, 5, Gramado, Bol. Resumos Expandidos, Gramado, SBG. 281-283.

Ferrando, L., Fernández, A., 1971. Esquema tectónico cronoestratigráfico del Predevoniano en Uruguay. In: XXV Congresso Brasileiro de Geologia. 1. pp. 199-210.

Florisbal, L.M., Heaman, L.M., de Assis Janasi, V., de Fatima Bitencourt, M., 2014. Tectonic significance of the Florianópolis dyke Swarm, Paraná-Etendeka Magmatic Province: a reappraisal based on precise U-Pb dating. J. Volcanol. Geotherm. Res. 289, 140-150.

Fragoso-Cesar, A.R.S., 1980. O Cráton do Río de la Plata e o Cinturão Dom Feliciano no Escudo Uruguaio-Sul-Riograndense. In: Congresso Brasileiro de Geologia. 5. pp. 2879-2892 31, SBGeol. Camboriú Anais.

Fragoso-Cesar, A.R.S., 1991. Tectônica de Placas no Ciclo Brasiliano: As Orogenias dos Cinturões Dom Feliciano e Ribeira no Rio Grande do Sul. (São Paulo. PhD Tesis, IGUSP. 367pp).

Fragoso-Cesar, A.R.S., Machado, R., Gomez Rifas, C., 1987. Observações sobre o Cinturão Dom Feliciano no Escudo Uruguaio e correlações com o Escudo do Rio Grande do Sul In: Simp. Sul-Bras. Geol., 3, SBGeol., núcleo Sureste, Curitiba, Atas. 2. pp. 791-809.

Gaucher, C., Frei, R., Chemale, F., Frei, D., Bossi, J., Martínez, G., Cernuschi, F., 2011. Mesoproterozoic evolution of the Río de la Plata Craton in Uruguay: at the heart of Rodinia? Int. J. Earth Sci. 100 (2-3), 273-288.

Gawthorpe, R.L., Hurst, J.M., 1993. Transfer zones in extensional basins: their structura style and influence on drainage development and stratigraphy. J. Geol. Soc. 150 (6), 1137-1152.

Geosoft incorporated(C), 2016. Software for Earth Science 1 Mapping and Processing [Oasis Montaj]. Geosoft Inc. Ltd.. www.geosoft.com.

Girardi, V.A.V., Teixeira, W., Mazzucchelli, M., da Costa, P.C., 2013. Sr-Nd constraints and trace-elements geochemistry of selected Paleo and Mesoproterozoic mafic dikes and related intrusions from the South American Platform: Insights into their mantle sources and geodynamic implications. J. S. Am. Earth Sci. 41, 65-82.

Gómez Rifas, C., 1989. Tectónica Cretácica en Uruguay. In: Contribuciones de los Simposios sobre Cretácico de América Latina. Parte A: Eventos y Registro Sedimentario, pp. 319-325.

Gómez Rifas, C., 1995. A Zona de Cisalhamento Sinistral de Sierra Ballena no Uruguay. PhD Thesis. IG-USP (243pp).

Gómez Rifas, C., Masquelin, H., 1996. Petrología y geoquímica de las rocas volcánicas cretácicas del Uruguay. In: XIII Congreso Geológico Argentino y III Congreso de Exploración de Hidrocarburos. Actas, Buenos Aires, pp. 650-652 13-18 Oct.

Gupta, V.K., Ramani, N., 1982. Optimum second vertical derivatives in geologic mapping and mineral exploration. Geophysics 47 (12), 1706-1715.

Gürbüz, A., 2010. Geometric characteristics of pull-apart basins. Lithosphere 2 (3), 199-206.

Halls, H.C., Campal, N., Davis, D.W., Bossi, J., 2001. Magnetic studies and U-Pb geochronology of the Uruguayan dyke swarm, Río de la Plata craton, Uruguay: paleomagnetic and economic implications. J. S. Am. Earth Sci. 14 (4), 349-361.

Hanski, E., Mertanen, S., Rämö, T., Vuollo, J., 2006. Dyke Swarms-Time Markers of Crustal Evolution: Selected Papers of the Fifth International Dyke Conference in Finland, Rovaniemi, Finland, 31 July-3 Aug 2005 \& Fourth International Dyke Conference, Kwazulu-Natal, South Africa 26-29 June 2001.

Hartmann, L.A., Leite, J.A.D., Da Silva, L.C., Remus, M.V.D., McNaughton, N.J., Groves, D.I., Fletcher, I.R., Santos, J.O.S., Vasconcellos, M.A.Z., 2000. Advances in SHRIMP geochronology and their impact on understanding the tectonic and metallogenic evolution of southern Brazil. Aust. J. Earth Sci. 47 (5), 829-844.

Henderson, R.G., Zietz, I., 1949. The computation of second vertical derivatives of geomagnetic fields. Geophysics 14 (4), 508-516.

Hinze, W., Frese, R., Saad, A., 2012. Gravity and Magnetic Exploration, Principles, Practices and Applications. Cambridge University Press, pp. 515.

Hood, P., 1965. Gradient measurement in aeromagnetic surveying. Geophysics 30, 891-902.

Hou, G., Kusky, T.M., Wang, C., Wang, Y., 2010. Mechanics of the giant radiating Mackenzie dyke swarm: a paleostress field modeling. J. Geophys. Res. 115, B02402. https://doi.org/10.1029/2007JB005475.

Hsu, S.K., 2002. Imaging magnetic sources using Euler's equation. Geophys. Prospect. 50, 15-25.

Hueck, M., Oriolo, S., Dunkl, I., Wemmer, K., Oyhantçabal, P., Schanofski, M., Basei, M.A.S., Siegesmund, S., 2017. Phanerozoic low-temperature evolution of the Uruguayan Shield along the South American passive margin. J. Geol. Soc. 174 (4), 609-626.

Jolly, R.J.H., Sanderson, D.J., 1995. Variation in the form and distribution of dykes in the Mull swarm, Scotland. J. Struct. Geol. 17 (11), 1543-1557.

Jones, G., 1956. Memoria Explicativa y Mapa Geológico de la Región Oriental del Departamento de Canelones. 34 Boletín del Instituto Geológico del Uruguay (193p).

Jones, G., 1957. Some deep Mesozoic basins recently discove red in Southern Uruguay. In: Proc. XX Congreso Geológico Internacional (Mexico, 1956), Secc. II (El Mesozoico del Hemisferio Occidental y sus correlaciones mundiales), pp. 53-72 (México).

Khattach, D., Keating, P., Mostafa, M.L., Chennouf, T., Andrieux, P., Milhi, A., 2004. Apport de la gravimétrie à l'étude de la structure du bassin des Triffa (Maroc nordoriental): implications hydrogéologiques. Compt. Rendus Geosci. 336, 1427-1432.

Khattach, D., Mraoui, H., Sbibih, D., Chennouf, T., 2006. Analyse multiéchelle par ondelettes des contacts géologiques: application à la carte gravimétrique du Maroc nord-oriental. Compt. Rendus Geosci. 338, 521-526.

Kinabo, B.D., Atekwana, E.A., Hogan, J.P., Modisi, M.P., Wheaton, D.D., Kampunzu, A.B., 2007. Early structural development of the Okavango rift zone, NW Botswana. J. Afr Earth Sci. 48 (2-3), 125-136.

Lenz, C., Fernandes, L.A.D., McNaughton, N.J., Porcher, C.C., Koester, E., Masquelin, H., 2011. Magmatic and metamorphic U-Pb SHRIMP ages in zircons for the Cerro Olivo Gneissic complex orthogneisses-Dom Feliciano Belt in Uruguay. Precambrian Res. 
185, 149-163.

Lezzar, K.E., Tiercelin, J.J., De Batist, M., Cohen, A.S., Bandora, T., Van Rensbergen, P., Klerkx, J., 1996. New seismic stratigraphy and Late Tertiary history of the North Tanganyika Basin, East African Rift system, deduced from multichannel and highresolution reflection seismic data and piston core evidence. Basin Res. 8 (1), 1-28.

Logatchev, N.A., 1993. History and Geodynamics of the Baikal Rift (East Siberia): A Review: Bulletin du Centre de la Recherche Exploration Production Elf Aquitaine. 17. pp. 353-370.

Lossada, A.C., Rapalini, A.E., Sánchez Bettucci, L., 2014. Enjambre de diques básicos de Nico Pérez-Zapicán, Uruguay: evidencias radiométricas y paleomagnéticas sobre su edad. Rev. Asoc. Geol. Argent. 71 (3), 345-355.

Maldonado, S., Piñeyro, D., Bossi, J., 2003. Terreno Piedra Alta - Aporte a la estratigrafía del basamento cristalino de Uruguay. Revista de la Sociedad Uruguaya de Geología, Spec. Pub. 1, 18-37.

Masquelin, H., 1990. Análisis estructural de las zonas de cizalla en las migmatitas de Punta del Este-Uruguay. Acta Geol. Leopold. 30, 139-158.

Masquelin, H., 2006. El Escudo Uruguayo. In: Cuencas Sedimentarias de Uruguay, geología, paleontología y recursos minerales: Paleozoico (Veroslavsky G., Martínez S. y Ubilla M. eds.), Montevideo, t.3, 37-106.

Masquelin, H., Aiffa, T., Muzio, R., Hallot, E., Veroslavsky, G., Bonnevalle, L., 2009. The Cuaró Mesozoic doleritic dyke swarm, southern Paraná basin, Uruguay: examples of superimposed magnetic fabrics? Comptes Rendus Géoscience 341 (12), 1003-1015.

Masquelin, H., D’Avila Fernandes, L.A., Lenz, C., Porcher, C.C., McNaughton, N.J., 2012. The Cerro Olivo complex: a pre-collisional Neoproterozoic magmatic arc in Eastern Uruguay. Int. Geol. Rev. 54 (10), 1161-1183.

Masquelin, H., Lara, H.S., Bettucci, L.S., Nuñez Demarco, P., Pascual, S., Muzio, R., Peel, E., Scaglia, F., 2017. Lithologies, structure and basement-cover relationships in the schist belt of the Dom Feliciano Belt in Uruguay. Brazilian Journal of Geology 47 (1), 21-42.

Mazzucchelli, M., Rivalenti, G., Piccirillo, E.M., Girardi, V.A.V., Civetta, L., Petrini, R., 1995. Petrology of the Proterozoic mafic dyke swarms of Uruguay and constraints on their mantle source composition. Precambrian Res. 74 (3), 177-194.

Modisi, M.P., Atekwana, E.A., Kampunzu, A.B., Ngwisanyi, T.H., 2000. Rift kinematics during the incipient stages of continental extension: evidence from the nascent Okavango rift basin, Northwest Botswana. Geology 28 (10), 939-942.

Mohriak, W.U., Rosendahl, B.R., Turner, J.P., Valente, S.C., 2002. Crustal architecture of South Atlantic volcanic margins. In: Menzies, M.A., Klemperer, S.L., Ebinger, C.J., Baker, J. (Eds.), Volcanic Rifted Margins. 362. Geological Society of America, Boulder, Colorado, pp. 159-202 Spec. Paper.

Morales, E., Muzio, R., Veroslavsky, G., Conti, B., 2006. Geología de la Sierra de los Ajos (Cuenca Laguna Merín, Rocha, Uruguay)/Geology of the Sierra de los Ajos (Laguna Merín basin, Rocha, Uruguay). 13. Revista SUG, pp. 2-8.

Morales, M., Oyhantçabal, P., Stein, K.-J., Siegesmund, S., 2010. Black dimensional stones: geology, technical properties and deposit characterization of the dolerites from Uruguay. Environ. Earth Sci. https://doi.org/10.1007/s12665-010-0827-5.

Morley, C.K., Nelson, R.A., Patton, T., LMunn, S.G., 1990. Transfer zones in the East African Rift System and their relevance to hydrocarbon exploration in rifts. AAPG Bull. 74 (8), 1234-1253.

Mubu, M.S., 1995. Aeromagnetic Mapping and Interpretation of Mafic Dyke Swarms in Southern Africa. M.Sc. thesis. Dept. of Earth Resource Surveys, International Institute for Aerospace Survey and Earth Sciences, Delft, the Netherlands.

Muzio, R., 2000. Evolução petrológica e geocronologia do Maciço Alcalino Valle Chico Uruguai. PhD Thesis. Universidade Estadual Paulista (171 pp).

Muzio, R., 2006. El magmatismo mesozoico en Uruguay y sus recursos minerales. In: Veroslavsky, G., Martínez, S., Ubilla, M. (Eds.), Cuencas Sedimentarias de Uruguay, geología, paleontología y recursos minerales: Mesozoico, pp. 77-102 Montevideo.

Muzio, R., Artur, A.C., Wernick, E., 2002. Petrological and geochemical evolution of the alkaline Valle Chico Massif, southeastern Uruguay. Int. Geol. Rev. 44 (4), 352-369.

Muzio, R., Morales, E., Veroslavsky, G., Conti, B., 2009a. The Arequita formation (Lower Cretaceous): petrographic features of the volcanic facies in the Laguna Merín Basin, East Uruguay. Latin American journal of sedimentology and basin analysis 16 (1), 19-28.

Muzio, R., Peel, E., Morales, E., Veroslavsky, G., Conti, B., 2009b. Mesozoic magmatism in East Uruguay: petrological constraints related to the Sierra San Miguel region. Earth Sciences Research Journal 13 (1), 16-29.

Núñez Demarco, P., Goso, C., Sánchez Bettucci, L., 2013. Estudio magnético en estructuras de canal en Villasboas, Flores, Uruguay. Latinmag Letters 3, 1-4.

Núñez Demarco, P., Masquelin, H., Sánchez Bettucci, L., 2018. Historia de la geología precámbrica de Uruguay: Revisión de las divisiones estructurales, tectoestratigráficas sus límites y nomenclaturas. Revista Investigaciones, Montevideo 1 (2), 1-16.

Núñez Demarco, P., Masquelin, H., Peel, E., Sánchez Bettucci, L., 2019a. Stratigraphy and tectonic setting of the Barriga Negra Formation in Uruguay: an update. Brazilian Journal of Geology 49 (1).

Núñez Demarco, P., Masquelin, H., Loureiro, J., Prezzi, C., Sánchez Bettucci, L., 2019b. Historia de la Geología Precámbrica de Uruguay: Unidades del Cinturón Dom Feliciano y su basamento. Revista Investigaciones, Montevideo 2 (1), 36-57.

Oriolo, S., Oyhantçabal, P., Heidelbach, F., Wemmer, K., Siegesmund, S., 2015. Structural evolution of the Sarandí del Yí Shear Zone, Uruguay: kinematics, deformation conditions and tectonic significance. Int. J. Earth Sci. 104 (7), 1759-1777.

Oriolo, S., Oyhantçabal, P., Wemmer, K., Basei, M.A., Benowitz, J., Pfänder, J., Hannich, F., Siegesmund, S., 2016a. Timing of deformation in the Sarandí del Yí Shear Zone, Uruguay: implications for the amalgamation of western Gondwana during the Neoproterozoic Brasiliano-Pan-African Orogeny. Tectonics 35 (3), 754-771.

Oriolo, S., Oyhantçabal, P., Wemmer, K., Heidelbach, F., Pfänder, J., Basei, M.A.S. Hueck, M., Hannich, F., Sperner, B., Siegesmund, S., 2016b. Shear zone evolution and timing of deformation in the Neoproterozoic transpressional Dom Feliciano Belt, Uruguay. J. Struct. Geol. 92, 59-78.

Oyhantçabal, P., 2005. The Sierra Ballena Shear Zone: Kinematics, Timing and its Significance for the Geotectonic Evolution of Southeast Uruguay. PhD Thesis. Georg August-University, Gottingen (139p).

Oyhantçabal, P., Siegesmund, S., Wemmer, K., 2010. The Río de la Plata Craton: a review of units, boundaries, ages and isotopic signature. Int. J. Earth Sci. 100 (2-3), 201-220.

Oyhantçabal, P., Heimann, A., Miranda, S., 2001. Measurement and interpretation of strain in the syntectonic Solís de Mataojo granitic complex, Uruguay. J. Struct. Geol. 23 (5), 807-817.

Oyhantçabal, P., Siegesmund, S., Wemmer, K., Presnyakov, S., Layer, P., 2009. Geochronological constraints on the evolution of the southern Dom Feliciano Belt (Uruguay). J. Geol. Soc. 166 (6), 1075-1084.

Oyhantçabal, P., Siegesmund, S., Wemmer, K., Passchier, C.W., 2011. The transpressional connection between Dom Feliciano and Kaoko belts at 580-550 Ma. Int. J. Earth Sci. 100 (2-3), 379-390.

Peate, D.W., 1997. The Paraná-Etendeka Province. In: Mahoney, J.J., Coffin, M.E. (Eds.), Large Igneous Provinces in Continental, Oceanic and Planetary Flood Volcanism. Geophys. Monogr. Series 100. American Geophysical Union, Washington DC, pp. 217-245.

Peel, E., Bettucci, L.S., Basei, M.A.S., 2018. Geology and geochronology of Paso del Dragón complex (northeastern Uruguay): implications on the evolution of the Dom Feliciano Belt (Western Gondwana). J. S. Am. Earth Sci. 85, 250-262.

Pinet, N., Lavoie, D., Keating, P., Brouillette, P., 2008. Gaspé belt subsurface geometry in the northern Québec Appalachians as revealed by an integrated geophysical and geological study: 1 - Potential field mapping. Tectonophysics 460, 34-54.

Porada, H., 1979. The Damara-Ribeira Orogen of the Pan-African-Brasiliano Cycle in Namibia (SW Africa) and Brazil as interpreted in terms of Continental Collision. Tectonophysics 57, 237-265.

Porada, H., 1989. Pan-African rifting and orogenesis in southern to equatorial Africa and eastern Brazil. Precambrian Res. 44 (2), 103-136.

Prave, A.R., 1996. Tale of three cratons: Tectonostratigraphic anatomy of the Damara orogen in northwestern Namibia and the assembly of Gondwana. Geology 24 (12), 1115-1118.

Preciozzi, F., Spoturno J., Heinzen, J. (1979): Carta Geo-Estructural del Uruguay escala 1: 2.000.000, Ministerio de Industria y Energía. Montevideo.

Preciozzi F., Spoturno J., Heinzen W., Rossi P. 1985. Memoria Explicativa de la Carta Geológica del Uruguay a la escala 1:500.000. DINAMIGE-MIEM. Montevideo, 90p

Preciozzi, F., Masquelin, H., Basei, M.A.S., 1999. The Namaqua/Grenville Terrane of Eastern Uruguay. In: South American Symp. On Isotope Geology, 2, Abstracts. Asoc. Geol. Argentina. Carlos Paz.

Rapela, C.W., Pankhurst, R.J., Casquet, C., Fanning, C.M., Baldo, E.G., González-Casado, J.M., Galindo, C., Dahlquist, J., 2007. The Río de la Plata craton and the assembly of SW Gondwana. Earth-Sci. Rev. 83, 49-82.

Ravat, D., 1996. Analysis of the Euler method and its applicability in environmental magnetic investigation. J. Environ. Eng. Geophys. 1, 229-238.

Reeves, C., 2000. The geophysical mapping of Mesozoic dyke swarms in southern Africa and their origin in the disruption of Gondwana. J. Afr. Earth Sci. 30 (3), 499-513.

Reid, A.B., 2003. Euler magnetic structural index of a thin-bed fault. Geophysics 68 (4), 1255-1256.

Reid, A.B., Allsop, J.M., Granser, H., Millett, A.T., Somerton, I.W., 1990. Magnetic interpretation in three dimensions using Euler deconvolution. Geophysics 55 (1), 80-91.

Reitmayr, G., 2001. Una espectacular peculiaridad uruguaya: la anomalía gravimétrica de la Laguna Merín. $15^{\circ}$ Congreso Latinoamericano de Geología/3 Congreso Uruguayo de Geología, Montevideo.

Renne, P., Ernesto, M., Pacca, I.G., Coe, R.S., Prévot, M., Perrin, M., 1992. The age of Paraná flood volcanism, rifting of Gondwanaland, and the Jurassic-Cretacous boundary. Science 258 (5084), 975-979.

Renne, P.R., Deckart, K., Ernesto, M., Fe, G., Piccirillo, E.M., 1996. Age of the Ponta Grossa dike swarm (Brazil), and implications to Paraná flood volcanism. Earth Planet. Sci. Lett. 144 (1-2), 199-211.

Reynolds, J., 2011. An Introduction to Applied and Environmental Geophysics, Second edition. Wiley - Blackwell, pp. 696.

Roest, W.R., Pilkington, M., 1993. Identifying remanent magnetization effects in magnetic data. Geophysics 58 (5), 653-659.

Roest, W.R., Verhoef, J., Pikington, M., 1992. Magnetic interpretation using the 3-D analytic signal. Geophysics 57, 116-125.

Rossello, E.A., de Santa Ana, H., Veroslavsky, G., 1999. El Lineamiento Santa LucíaAiguá- Merín (Uruguay): Un rifting transtensivo Mesozoico abortado durante la apertura Atlántica? In: $5^{\circ}$ Simpósio sobre o Cretáceo do Brasil - $1^{\circ}$ Simposio sobre el Cretácico de América del Sur, Serra Negra. Actas. 1. pp. 443-448.

Rossello, E.A., De Santa Ana, H., Veroslavsky, G., 2000. El lineamiento Santa Lucía-AiguáMerín (Uruguay): Un corredor tectónico extensivo y transcurrente dextral precursor de la apertura atlántica. Rev. Bras. Geosci. 30 (4), 749-756.

Rossello, E.A., Veroslavsky, G., De Santa Ana, H., 2001. Influencias del Lineamiento transtensivo Santa Lucía-Aiguá-Merín sobre el emplazamiento del magmatismo alcalino cretácico del Cratón La Plata (Uruguay): aportes a la prospección diamantífera Revista Brasileira de Geociências 31 (2), 163-168 (Brasilia).

Rossello, E.A., Veroslavsky, G., Masquelin, H., 2007. El corredor Juro-Cretácico Santa Lucía-Aiguá-Merín (Uruguay): cinemática transcurrente dextral y controles preexistentes. Rev. Asoc. Geol. Argent. 62 (1), 92-104.

Rossello, E.A., Veroslavsky, G., de Santa Ana, H., Rodríguez, P., 2018. Geology of the Río de la Plata and the surrounding areas of Argentina and Uruguay related to the evolution of the Atlantic margin. J. S. Am. Earth Sci. 83, 147-164.

Salem, A., Smith, R., 2005. Depth and structural index from normalized local 
wavenumber of 2D magnetic anomalies. Geophys. Prospect. 53 (1), 83-89.

Salomon, E., Koehn, D., Passchier, C., 2015a. Brittle reactivation of ductile shear zones in NW Namibia in relation to South Atlantic rifting. Tectonics 34 (1), 70-85.

Salomon, E., Koehn, D., Passchier, C., Hackspacher, P.C., Glasmacher, U.A., 2015b. Contrasting stress fields on correlating margins of the South Atlantic. Gondwana Res. 28 (3), 1152-1167.

Salomon, E., Passchier, C., Koehn, D., 2017. Asymmetric continental deformation during South Atlantic rifting along southern Brazil and Namibia. Gondwana Res. 51, $170-176$.

Sánchez Bettucci, L., Mezzano, A., 1993. Análisis Sedimentológico y faciológico de la Forma-ción Rocha (Ex-Grupo Rocha): Revista Brasilera de Geociencias. 23. pp. 323-329.

Sánchez Bettucci, L., Rapalini, A., 2002. Paleomagnetism of the Sierra de Las Anima complex, southern Uruguay: its implications in the assembly of western Gondwana. Precambrian Res. 118 (3-4), 243-265.

Sánchez Bettucci, L., Peel, E., Masquelin, H., 2010. Neoproterozoic tectonic synthesis of Uruguay. Int. Geol. Rev. 52 (1), 51-78.

Sánchez Bettucci, L., Loureiro, J., Pascale, A., Faraone, M., Guerrero, S., 2016. Relevamiento geofísico aeroportado de la porción sur del Uruguay. VIII Congreso Uruguayo de Geología, Montevideo, Uruguay.

Serra, N., 1944. Memoria explicativa del Mapa Geológico del Departamento de Treinta y Tres (escala 1:250.000). Boletín del Instituto Geológico del Uruguay 31, 1-43 Montevideo.

SGM - Servicio Geográfico Militar, 1973. Carta gravimétrica provisoria, escala 1:100.000. Conv. ANCAP-SGM, memoria, 1 mapa. Montevideo.

Silva, J.B.C., 1996. 2-D magnetic interpretation using the vertical integral. Geophysics 61, 387-393.

Spoturno, J., Loureiro, J., Oyhantçabal, P., Pascale, A., J. 2012.). Mapa geológico del Departamento de Maldonado escala 1:100.000. Dirección Nacional de Minería y Geología (MIEM) - Facultad de Ciencias (UdelaR)-, Montevideo.

Stewart, K., Turner, S., Kelley, S., Hawkesworth, C., Kirstein, L., Mantovani, M., 1996. 3 D, Ar40-Ar39 geochronology in the Paraná continental flood basalt province. Earth Planet. Sci. Lett. 143, 95-109.

Strugale, M., Rostirolla, S.P., Mancini, F., Portela Filho, C.V., Ferreira, F.J.F., de Freitas, R.C., 2007. Structural framework and Mesozoic-Cenozoic evolution of Ponta Grossa Arch, Paraná Basin, southern Brazil. J. S. Am. Earth Sci. 24 (2-4), 203-227.
Teixeira, W., Renne, P.R., Bossi, J., Campal, N., D’Agrella Filho, M.S., 1999. 40Ar-39Ar and $\mathrm{Rb}-\mathrm{Sr}$ geochronology of the Uruguayan dyke swarm, Río de la Plata Craton and implications for Proterozoic intraplate activity in western Gondwana. Precambrian Res. 93 (2), 153-180

Teixeira, W., Pinese, J.P.P., Iacumin, M., Girardi, V.A.V., Piccirillo, E.M., Echeveste, H., Heaman, L.M., 2002. Calc-alkaline and tholeiitic dyke swarms of Tandilia, Río de la Plata craton, Argentina: U-Pb, Sm-Nd, and $\mathrm{Rb}-\mathrm{Sr} 40 \mathrm{Ar} / 39 \mathrm{Ar}$ data provide new clues for intraplate rifting shortly after the Trans-Amazonian orogeny. Precambrian Res. 119 (1-4), 329-353.

Teixeira, W., D'Agrella-Filho, M.S., Hamilton, M.A., Ernst, R.E., Girardi, V.A., Mazzucchelli, M., Bettencourt, J.S., 2013. U-Pb (ID-TIMS) baddeleyite ages and paleomagnetism of 1.79 and $1.59 \mathrm{Ga}$ tholeiitic dyke swarms, and position of the Río de la Plata Craton within the Columbia supercontinent. Lithos 174, 157-174.

Thiede, D.S., Vasconcelos, P.M., 2010. Paraná flood basalts: rapid extrusion hypothesis confirmed by new 40Ar/39Ar results. Geology 38 (8), 747-750.

Thompson, D.T., 1982. EULDPH: a new technique for making computer assisted depth estimates from magnetic data. Geophysics 47, 31.

Trumbull, R.B., Vietor, T., Hahne, K., Wackerle, R., Ledru, P., 2004. Aeromagnetic mapping and reconnaissance geochemistry of the Early Cretaceous Henties Bay-Outjo dike swarm, Etendeka igneous province, Namibia. J. Afr. Earth Sci. 40 (1-2), 17-29.

Vaughan, A.P., Pankhurst, R.J., 2008. Tectonic overview of the West Gondwana margin. Gondwana Res. 13 (2), 150-162.

Veroslavsky G., Martínez S. y Ubilla M. (ed) (2006) Cuencas Sedimentarias de Uruguay Mesozoico, DIRAC Facultad de Ciencias: http://cuencas.fcien.edu.uy/extension/ Cuencas\%20Sedimentarias\%20-\%20Mesozoico.pdf.

Will, T.M., Frimmel, H.E., 2013. The influence of inherited structures on dike emplacement during Gondwana breakup in southwestern Africa. The Journal of Geology 121 (5), 455-474.

Will, T.M., Frimmel, H.E., 2018. Where does a continent prefer to break up? Some lessons from the South Atlantic margins. Gondwana Res. 53, 9-19.

Yao, C.L., Guan, Z.N., Wu, Q.B., Zhang, Y.W., Liu, H.J., 2004. An analysis of Euler deconvolution and its improvement. Geophysical \& Exploration (in Chinese) 28 (2), 150-154.

Zerfass, H., Chemale Jr., F., Lavina, E., 2005. Tectonic control of the Triassic Santa Maria Supersequence of the Paraná Basin, southernmost Brazil, and its correlation to the Waterberg Basin, Namibia. Gondwana Res. 8 (2), 163-176. 